\title{
Devolution of OIL AND Gas JuRisdiction to FirST NaTIONS IN CANADA
}

\section{ALEXANDER J. BLACK*}

This article examines the history and purpose of the First Nations Oil and Gas and Moneys Management Act, which enables the devolution of the managemem and regulation of oil and gas exploration io First Nations. The author provides an analysis of the Acl is salient provisions and the prerequisites to accession to the oil and gas managemen and moneys regime.
Cel article porte sur thistoire en la ruisen d'etre de la Loi sur la gestion du pétrole et du gaz et des fonds des Premieres nations, qui permet le tramsfert des responsabilites relatives is la gession el la réglementation de l'exploration pitrolicire el gazière aux Premières notions. L auteur donne une anolyse des dispositions importantes de la Loi ainsi que des conditions préulables à l'accession à la gestion du pétrole et du gaz et à ses fonds.

\section{TABLE OF CONTENTS}

I. INTRODUCTION .............................. 538

II. NON-RENEWABLE RESOURCE EXPLOITATION

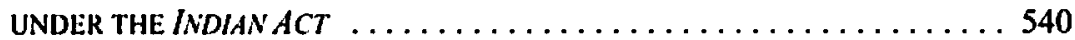

III. THE INDIAN OLL AND GAS ACT, ROYALTIES,

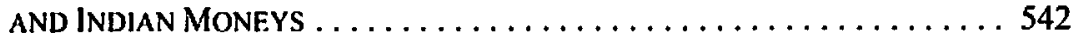

A. REFERENTIAL INCORPORATION OF PROVINCIAL LAWS $\ldots \ldots \ldots 548$

B. SURFACE ACCESS UNDER TIIE INDIAN OIL AND GAS ACT ..... 550

C. ENVIRONMENTAL ASSESSMENT UNDER

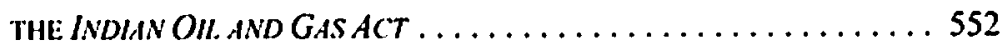

IV. NEgOTIATIONS WITH FIRST NATIONS LEADING TO THF.

FIRST NITIONS OIL AND GAS MONEVS MANAGEMENT ACT ........ 554

V. ACCESSION TO THE OIL AND GAS MANAGEMENT REgIME ........ 558

A. Prerequisites of the Transfer Agreement $\ldots \ldots \ldots \ldots .560$

B. OWNERSHIP RIGHTS, LAW MAKING POWERS.

AND RESPONSIBILITIES $\ldots \ldots \ldots \ldots \ldots \ldots \ldots \ldots \ldots \ldots 2$

C. STATUTORY ASSIGNMENT OF LEASES AND

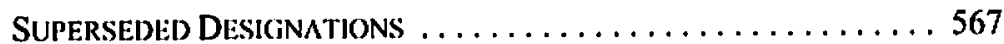

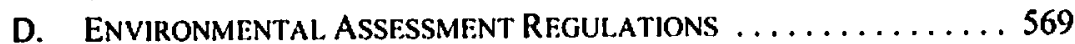

E. ENVIRONMENTAL PROTECTION AND OIL AND Gas Conservation ................. 571

F. First Nation Agreement WITII Province and

REFERENTIAL INCORPORATION OF LAW $\ldots \ldots \ldots \ldots \ldots \ldots, 573$

G. ACCESSION TO THE MONEYS RIEIME .............. 574

H. Depleting AsSets and First Nations'

BUSINESS ACUMEN ........................ 578

I. ADVANCED TAX RULING .................... 581

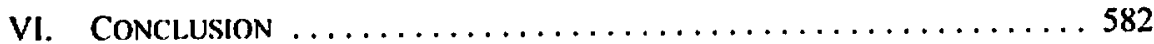

B.A. (Hons.) Lakehead University; LL.B. Dip. Petrol. Law, University of Dundec, Scotland; L.L.M. University of British Columbia; Counsel, Aboriginal Law Services, Department of Justice Canada. Calgary, Alberta. This anicle reflects the author's views and not necessarily those of the Department of Justice nor the Government of Canada. 


\section{INTRODUCTION}

Just before the prorogation of the Canadian Parliament and subsequent 2006 General Election, the First Nations Oil and Gas and Moneys Management Act' was enacted on Monday, 28 November 2005. The FNOGMMA enables the devolution of the management and regulation of oil and gas exploration to First Nations ("bands" under the Indian Acr') who accede to the new management regime. It also enables a First Nation, who accedes to the distinct FNOGMMA moneys regime, to obtain and control certain moneys held by Canada for the benefit of the First Nation under earlier legislation.

This article identifies the history and purpose of the new $A c t$, its salient provisions, and the steps which a First Nation must take in order to accede into either or both of the two new regimes (management and moneys). Once a First Nation accedes to the FNOGMMA management regime, it will assume the managerial authority of oil and gas exploration and exploitation on the respective Indian reserve, an authority currently exercised by Indian Oil and Gas Canada (IOGC). which is a special operating agency of the department of Indian Allairs and Northern Development (DIAND). It will also directly receive all the revenues from oil and gas exploration and exploitation from the date of accession onwards. Once a First Nation accedes to the FNOGMMA moneys regime, it will receive from Canada the Indian moneys, currently held in the Consolidated Revenue Fund (CRF) by Canada under the Indian Act and the Financial Administration $A c t,{ }^{3}$ whether those moneys pertain to oil and gas operations (including royalties and bonuses) or other non-resource operations.

The objective of this article is to provide an analysis of FNOGMMA as a legal instrument for economic development on Indian reserves in Canada. Consequently, much attention is paid to the necessary referendum of First Nation members, secondary legislation, intergovernmental agreements, and other steps necessary to enable a First Nation to accede to either or both of two new regimes (management and moneys). Accession to the two new regimes will involve a transition from an existing regime, thus this article begins by jdentifying the restricted ambit, criticisms, and supervening commercial issues which followed the 1974 Indian Oil and Gas $A c t$ and Regulations."

The new Act is a signilicant milestone in First Nations governance as it represents the legislative culmination of extensive efforts between Canada and First Nations concerning oil and gas on Indian reserves. For example, in the mega-suit Samson Indian Band v. Canada (Minister of Indian Affairs and Northern Development), the judge could "only marvel at the

S.C. 2005, c. 48 [FNOGMMA]. The long title is "An Act to provide lirst nations with the option of managing and regulating oil and gas exploration and exploitation and of receiving moncys othenwise lueld for them by Canada."

$=\quad$ R.S.C. 1985, c. 1-5. s. $2(1)$.

R.S.C. 1985, c. F-I1.

- Imeliom Oil and Gas AC, S.C. 1974-75-76, c. 15. s. I, as an. by R.S.C. 1985, c. 1-7 [1OG Adr]: Indiem Oil and Gas Regulutions, S.O.R./94-753 [IOG Regulationss (1995)].

3 2005 FC 1622, 269 F.T.R. I [Samson Imdion Band]. This action was heard together with the action in Ermineskin Indian Band $v$. Canada (Minister of Indian Affairs and Northern Development). 2005 FC 1623, 269 F.T.R. 188. On 20 December 2006, a majority of the Federal Court of Appeal affimed the dismissal of both actions against Canada: Emineskin Indian Band and Nation v. Canada; Samson Indian Nation and Band v. Canada, 2006 FCA 4I5. [2007] 3 F.C.R. 245. On 15-16 February 2007, the 
numerous studies, presentations, projects, reports, reviews, and initiatives produced over the years by various committees, groups, and interested persons." "Thus the FNOGMMA oil and gas management regime is a legal instrument aimed at improving economic efficiency of First Nations.

Under FNOGMMA, when a First Nation accedes to the new management regime, it will have the ability to make its own laws concerning the exploitation of oil and gas, as opposed to having to contract under the aegis of IOGC, the statutory trustee and regulator under the similarly named $A c t$. A First Nation under FNOGMMA will have greater flexibility in the structuring of its oil and gas transactions when it accedes to the new management regime. For instance:

One of the most important things a formal propery system does is transform assets from a less accessible condition to a more accessible condition, so that they can do additional work. Unlike physical assets. representations are casily combined, divided, mobilized, and used to stimulate business deals. By uncoupling the economic feutures of un asset from their rigil, physical state, a representation makes the asset "fingible" - able to be fashioned to suit practically any transaction.?

The new $A C l$ accompanies other legislation which is part of an overall devolution process to transfer federal Canadian responsibilities and administrative authority to First Nations ${ }^{x}$ or territories ${ }^{9}$ subject to federal authority. It reflects aspects of the smart regulation initiatives of the federal Government. ${ }^{10}$ It also addresses a regulatory gap, where existing federal laws do not meet the needs of oil and gas activities on reserves and where provincial regulations

appellant First Nations filed an application for leave to appeal to the Supreme Court of Canada, and on 7 December 2007 leave to appeal was granted: Samson Indian Band : Conoda Minister of Indian Affairs and Northern Development), [2007] S.C.C.A. No. 85. 31869 (7 December 2007); Ermineskin Indian Band v. Camada (Minister of Indian Affairs and Northern Developmem), [2007] S.C.C.A. No. 8,631875 (7 December 2007). Samson Indian Band, ibid. at para. 786 [refierences omitted]:

The following list provides just a taste of these efforts: the 1969 White Paper; the aboriginal response contained in Citizens Plus, or the Red Paper; Indian Association of Alberta presentations and letters to the Minister of DIAND: the 1983 report of the all-party House of Commons Special Committec on Indian Self-Government, commonly known as the Penner Report: Bill C.52, the Indian Self-Government Acl, which llowed from the Penner Report; the 1984 Dion Report: community self-government initiatives of the mid-1980s; DIAND's Lands. Revenues \& Trusts (LRT) Review conducted in the late 1980s; the Hall Report; and more recently, the First Nations Land Mamagement Act and the First Nations Money Management Act, the latter of which failed to be enacted. Of course, this is not an exhaustive list. I note also that. in a very few cases, selfgovernment agreements have been successfully negotiated with specific First Nations.

- Hernando de Solo, The Mystery of Capiral: Why. Capitalism Triumphs in the West and Fails Everywhere Else (New York: Basic Books, 2000) at 56.

Firsi Nations Land Management Act. S.C. 1999, c. 24: First Nations Fiscol and Statistical Manugement Act, S.C. 2(105. c. 9; First Nations Commercial and Industrial Development Act. S.C. 2005. c. 53. Sec c.g. Camade-Yukon Oil and Gas Accord Implementation Act. S.C. 1998, c. 5, as am. by linkon Act. S.C. 2002 , c. 7.

10 Canada Privy Council Omice, Smony Regulusion: Report on Acrions amd Ploms (Fall 2005 Updalc). online: Government of Canada - Regulation <llup:/www.reglementation.ge.ca/does/report 1/rap_e.pdls at 4: "Smart Regulation involves a series of projects that strengthen the policies, processes, tools and communities needed to sustain high levels of regulatory performance and facilitate continuous improvement. Smart Regulation emphasizes ... securing the conditions for an innovative and prosperous economy." 
that apply to similar off-reserve projects do not apply on reserves for constitutional reasons. All four federal Canadian political parties (Liberal, Conservative, New Democratic Party, and Bloc Québecois) decided to fast-track four legislatives initiatives, including FNOGMMA, before the triggering of the 2005 General Election."

Somewhat similar to the European Union's (EU) principle of subsidiarity, ${ }^{12}$ the devolution process in general is partly based upon the notion that individual First Nations are best suited to implement measures for their particular circumstances. Furthermore, the new $A c t$ is a form of distributive justice. After all. since the time of Plato it has been suggested that "equality among unequals" may be inequitable and that differential treatment may be essential for real equality. ${ }^{13}$ This article therefore examines the purpose and prospects of the new $\mathrm{Act}$, particularly as a legal instrument aimed at facilitating economic development on First Nation land (Indian "reserves" as defined under the Indian $\mathrm{Act}^{14}$ ).

\section{NON-RENEWARI.E. RESOURCE EXPLOITATION UNDER THE INDIAN ACT}

In the non-Indian land context, the rights of mineral owners and surface owners depend on the terms of the instrument of severance, which is "often a reservation or exception of mineral rights on a sale of land from one private person to another." I5 In the context of Indian land, the instrument of severance is conjunctively contained in the following instruments: (1) designation; and (2) the mineral permit/lease (which typically requires an ancillary surface lease so that the owner of the minerals is legally able to enter upon the surface to work the minerals and sever them from the ground).

Tille to all Indian reserves is vested in the Crown for the use and benefit of the Indian band for whom the reserves were set apar. ${ }^{16}$ Sections 371041 of the Indian Act provide for

Allan Weods, "Parties agree to give four bills priority: MPs hope to pass legislation on home-heating rebates" Narional Post (15 November 2005) A4.

I: Sec "Subsidiarity." online: Europa <http://europa.cu.int/abc/eurojargon/index_en.htm>: "The 'subsidiarity principle' means that EU decisions must be taken as closely as possible to the citizen. In other words, the Union does not take action (exeept on matters for which it alome is responsible) unless EU action is more eflective than action taken al national, regional or local level." However, under the principle of proportionality. "Union action may not exceed "what is necessary to achieve the objectives of the Union"': see "Proportionality." online: The European Constitution <http://www.curopean constilution.ic/termsused.anp?>

1i Plato, Lants (Books 1-6), trans. by Benjamin Jowetl, online: Greck Texts <hutp://www.greektexts.com/ library/Plato/laws_(books_!_ - 6)/eng/322.html > al 74-75: "To this the legislalor should look-nol to the interests of tyrants one or more, or to the power of the people, but to justice always; which, as 1 was saying. the distribution of natural equality among uncequals in each case."

is Supra note 2, s. 2(1).

Barry J. Barton. Canadion Law of Mining (Calgary: Canadian Institute ol Resources Law, 1993) at 54. Indian det, supra note 2. s. 2(1): "reserve (a) means al Iract of land, the legal title to which is vested in ller Majesty. that has been set apart by Her Majesty for the use and benefit of a band, and (b) except in subsection 18(2), sections 20 to $25,28,36$ to $38,42,44,46,48$ to 51,58 to 60 and the regulations made under uny of those provisions, includes designated lands." Section $18(1)$ provides that: "Subject to this Acl. reserves are held by Her Majesty for the use and benelit of the respective bands for which tley were sel apart, and subject to this Acl and to the terms of any treaty or surrender. the Govemor in Council may determine whether any purpese for which lands in a reserve are used or are to be used is for the use and benefit of the band." While s. 36 of the Indian Act allows for reserves in which the title is not held by the Crown, the DIAND regards s. 36 as of historical interest only: sece the Indian and Northem Affairs Canada (INAC), Lamds Mtumagement Mamul, online: INAC <hitp://www.ainc-inac.ge.ca/ps/ 
surrenders and designations. Such lands may not be sold, leased, have their tilles conveyed, or have any interest in them granted until the lands have been surrendered to the Crown by the relevant Indian band. ${ }^{17}$

The term "designation" pertains to any surrender which is not absolutc.| Thus, designations are typically used for the exploitation of non-rencwable resources and in situations where there is a reversionary interest in favour of the band. Once lands in an Indian reserve are designated for oil and gas leasing, then the Minister of DIAND or a delegate is generally empowered to lease the designated lands, in accordance with the lerms of the designation. ${ }^{17}$ Further, s. 38(2) of the Indian Act states that "[a] band may, conditionally or unconditionally, designate, by way of a surrender 10 llor Majesty that is not absolutc, any right or interest of the band and its members in all or part of a reserve, for the purpose of its being leased or a right or interest therein being granted."

In 1988. Parliament created a two-tiered system of surrenders when s. 2(1) of the Indian Act was amended to provide: ". designated lands" means a tract of land or any interest therein the legal title to which remains vested in Her Majesty and in which the band for whose use and benefit it was set apart as a reserve has, otherwise than absolutely. released or surrendered its rights or interests, whether before or after the coming into force of this definition."21

The term "designated lands" was added to the Inclian Act in order to reverse the finding in Kamloops Indian Band v. British Columbia" that reserve lands surrendered solely for the purpose of leasing no longer constitute lands within a reserve for taxation purposes. These 1988 amendments ${ }^{23}$ were referred to as the Kamloops Amenklments by the Supreme Court of Canada in St. Mary's Indiam Band v. Cranbrook (City of $)^{24}$

The Kamloops Amendments created a two-tier system ol'surrenders which was intended to clarify the status of reserve lands surrendered for lease primarily for purposes of laxation. Surrenders for lease fall within the definition of designated lands, and surrenders for sale remain beyond the definition of reserve. The broad phrase "otherwise than absolutely" allows for other limited forms of surrenders (such as a right of way) to be considered designated land and yet ensures that other forms of permanent surrenders, be they conditional or unconditional (such as an exchange or gifi), remain beyond the notion of reserve land. Thus, in order to designate their land for oil and gas leasing. an Indian Band must elicit an affirmative result from its membership by way of referendum pursuant to $\mathrm{s}$. 39 of the Indian Act.

Its/lumm_e.html> at Directice I0-6.

Indian Act, supra nole 2. s. 37(1).

lhid., s. 2(1).

Ibid., s. 53(1).

lhid., s. 38(2).

lhid, s. 2(1) [emphasis added].

(1984), II D.L.R. (4th) 226 (B.C.C.A.).

S.C. 1988, c. 23. s. I. now R.S.C.1985 (4th Supp.), c. 17 [Kamloops Amendments].

[1997] 2S.C.R. 657.

Indian Act, supra note 2. s. 2(1). 


\title{
11I. THE INDIAN OLL AND GAS ACT, ROYALTIES, AND INDIAN MONEYS
}

Until 1977, the IOG Regulations ${ }^{26}$ were made pursuant to the Indian Act. The need for legislative change became apparent following the first global energy crisis in 1973, when oil prices rose dramatically. Non-oil petroleum prices rose too since they were indexed in relation to oil. On 20 December 1974, royal assent was given to the Indian Oil and Gas Act. ${ }^{27}$ The $A c t$ expressly applies to Indian lands (reserves) as defined by the Indian $A c t .^{28}$ Unfortunately, the flexibility that the Act promised could not be implemented until 22 April 1977 when the 1977 IOG Regulations ${ }^{29}$ were promulgated and when s. 4 of the $A C t$ was proclaimed in force. Since 22 April 1977, bands have had two broad choices in the structuring of their oil and gas leases.

Under the $I O G A C t$, royalties from oil and gas activities on Indian lands are to be paid to Canada in trust for the relevant band:

\begin{abstract}
Nowwitlsstanding any lerm or condition in any grant, Icase, permil, lieence or other disposition or any provision in any regulation respecting oil or gas or both oil and gas or the terms and conditions of any agrement respecting royalties in relation to oil or gas or both oil and gas, whether granled, issued, made or entered into before or after December 20,1974, but subject to subsection (2), all oil and gas obtained from Indian lands after April 22, 1977 is subject to the payment of Her Mcjesty in right of Canada, in trast for the Indian bands concerned, of the royalties prescribed from time to time by the regulations. ${ }^{30}$
\end{abstract}

Section 4(1) expressly stipulates that the royalties prescribed from time to time by the regulations must be paid to the Crown in trust for the relevant band. Alternatively, a band may choose to negotiate a special agreement pursuant to the $1 O G \mathrm{Act}$ : "The Minister may, with the approval of the council of the band concerned, enter into a special agreement with any person for a reduction or an increase, or a variation in the basis of calculation of royalties payable under subsection (1)."31

Bands utilize the relative flexibility of special agreements as opposed to royalties prescribed from time to time by the various IOG Regulations. Some of the reasons for this preference were discussed in Parliament during the debates which preceded the then proposed $1974 \mathrm{Act}$ :

[The $/ O G \mathrm{Act}$ enables the Minister of Indian Alfairs and Northern Development, after first getting the approval of the band concerned, to enter into special arrangements for reducing royalties where conditions

2n hid., s. 2: "“'Indian lands" means lands reserved for the Indians, including any interests therein, surrendered in accordance with the Indian $A c t$ and includes any lands or inleresis in lands described in any grant, lease, permit. licence or other disposition referred to in s. 5."

C.R.C. 1978, c. 963 [1OG Regulations (1977)].

IOG Act, supra note 4, s. 4 [emphasis added].

Ibid., s. 4(2). 
warrant that step. It provides that all oil and gas rights granted on Indian reserves may be subject to legislation which is suited to the industry conditions of the day. 32

Special agreements usually provide for the payment of a royalty, as well as other pecuniary and non-pecuniary terms, which are acceptable to the band and the lessee. In any event, the terms and conditions of an oil and/or gas lease on an Indian reserve require the joint concurrence of the Band Council and the Executive Director of IOGC. The Crown, through IOGC, acts in a dual capacity, as a lessor/proprietor and as a regulator. Its mandate is to "fulfill the Crown's fiduciary and statutory obligations related to the management of oil and gas resources on First Nation lands, and to further First Nation initiatives to manage and control their oil and gas resources." ${ }^{33}$

Generally speaking, in the Supreme Court of Canada decision Blueberry River Indian Band v. Canada (Department of Indian Affairs and Northern Development) ${ }^{34}$ the fiduciary principle was extrapolated into a prudent person test ${ }^{35}$ concerning the particular issue of surrendered mineral rights:

The matter comes down to this. The duty on the Crown as fiduciary was "that of a man of ordinary prudence in managing his own aflairs." A reasonable person does not inadvertenlly give away a potentially valuable asset which has already demonstrated carning potential. Nor does a reasonable person give away for no consideration what it will cost him nothing to keep and which may one day possess value, however remote the possibility. ${ }^{36}$

Further, in Wewaykum Indian Band v. Canada, ${ }^{37}$ the Supreme Court said that "ordinary diligence must be used by the Crown to avoid invasion or destruction of the band's quasiproperty interest by an exploitative bargain with third parties or, indeed, exploitation by the Crown itself." 38

Concerning its stewardship of oil and gas resources on Indian reserves, Canada would likely be held to the standard of ordinary diligence within the context of the IOG ACt, the IOG Regulations (1995), and the Indian Act. It is vitally important to note that this regime involves joint decision making by Canada and the Band Council. ${ }^{39}$ In particular, the $I O G$ Act and the IOG Regulations (1995) recite the need for "approval of the Band Council" at least

House of Commons Debates, Vol. 1 (21 October 1974) at 558 (Hon. Judd Buchanan (Minister of Indian Affairs and Northem Development)).

INAC. "Indian Oil and Gas Canada," online: INAC <http://www.aine-inac.ge.ca/ps/ts/ioge_c.html>; see also INAC. "Mission," online: IN AC <http:/www.ainc-inac.ge.ca/oil/vision_e.html>. [1995] 4 S.C.R. 344 [Apsassin].

Jbid. at pura. 102: "Secondly, the trial judge's inlerence from low value of the absenee of a duty to reserve the mineral from the 1948 transfer is suspect. If indeed the mineral rights had minimal sale value in 1948, it does not follow that a prudent person woukd give them." lbid. at para. 104 [relierences omitted].

3) 2002 SCC 79, [2(102) 4 S.C.R. 245. Ibid. at para. 100, Binnie J., explaining Guerin v. Canada. [198+1] 2 S.C.R. 335, referring to dpsussin. stupra nole 34.

:9 IOG Act, stupra note 4, s. 6(1): "The Minister. in administering. this Act, shall consult, on a continuing basis. persons representative of the Indian bands most direclly aflected thereby." 
cleven times ${ }^{\text {th }}$ and recites nine discrete requirements for consultation by the Executive Director with the Band Council. ${ }^{41}$

Under the IOG ACt regime, the First Nation income from oil and gas activities on Indian reserves is exempt from taxation because these moneys are deposited into the $\mathrm{CRF}^{42}$ and therefore considered "public money" as defined in the Financial Administration Act:

\begin{abstract}
"public moncy" means all moncy belonging to Canada received or collected by the Receiver General or any other public oflicer in his oflicial capacity or any person authorized to receive or collect such money, and includes
\end{abstract}

(d) all money that is paid to or receired or collected by a public olficer under or pursuant to any Act, trust. treaty. undertaking or contract. and is to be disbursed for a purpose specified in or pursuant to that Act, trust, trealy. underaking or contract. ${ }^{43}$

All public moncy is placed within the CRF, which is "the aggregate of all public moncys that are on deposit at the credit of the Receiver Gencral." moncys from oil and gas activities on Indian lands is a matter which concerns "Indian moneys." 45 But not all money is the same. Oil and gas royalties and bonuses pertaining to petroleum exploitation rights on Indian reserves are characterized as capital moneys under the Indian Act, requiring them to be handled in a special manner: "All Indian moneys derived from the sale of surrendered lands or the sale of capital assets of a band shall be deemed to be capital moneys of the band and all Indian moneys other than capital moneys shall be deemed to be revemie moneys of the band."

Section 62 of the Indian Act defines revenue moncys in terms of what they are not, as revenue moneys are deemed to be all Indian moneys other than capital moneys. More importantly, capital moneys are more tightly controlled than revenue moneys (which are characterized to include bonuses for seismic operations, surface rental from oil and gas operations, right of way and right of entry compensation). Section 64 of the Indian Act sets out a number of distinct purposes ${ }^{47}$ for the expenditure of the capital moneys, at the

Ibid., s. 4(2): J)( Rexulations (1995), supra note 4, ss. 10(1), 17(4), 2016), 24(11), 29, 36(2), 39(3), $42(1), 50,56(1)$.

IOG Regulations (1995), ibid, ss. 14(5), 2(41), 24(7), 24(8), 27(2)(b), 27(4), 33(6), 34(1), 38(2), 40(2).

Financial Admimistrotion Act, supra note 3, s. 2.

thid.

thid.

Indian Act, sumpa note 2. s. 2: "'-Indian moneys' means all moneys collected, received or held by ller Majesty for the use and benefit of Indians or bands."

to Ibid. 5. 62 (emphiasis added]: s. $61(1$ ): "Indian mencys shall be expended only lior the benefit of the Indians or hands for whose use and benefie in common the moneys are received or held. and subject to this Act and to the terms of any treaty or surrender, the Governor in Council may determine whether any purpose lior which Indian ntoncys are used or are to be used is for the use and benefit of the band": s. 61(2): "Interest on Indian moneys held in the Consolidated Revenue find" shall be allowed at a rate to be fixed from time to time by the Governor in Council."

t7 In addition to distincl purposes, s. $64(1)(k)$, ibid., provides for "any other purpose that in the opinion of the Minister is lor the benefit of the band." 
discretion of the Minister, providing that the Band Council consents. ${ }^{\text {t8 }}$ On the other hand, the test for the expenditure of revenue moneys, with the consent of the band, is broad and permissive. ". Unilaterally, the Minister may direct expenditures out of revenue moneys for certain purposes. ${ }^{50} \mathrm{Certain}$ bands may be authorized to manage and expend revenue moneys, a provision which is attractive for the purposes of First Nation self-governance. ${ }^{5 !}$

Consistent with the current regime, the Disposition Policy ${ }^{52}$ of the IOGC is a guideline approach currently used by that federal agency in evaluating and negotiating dispositions (permits and leases) of oil and gas rights on surrendered or designated reserve lands. As a public decision maker, the IOGC may not bind itself or feller its discretion by making general rules which apply to every case; each case must be decided on its own merits, although the decision maker may establish guidelines or general policies which assist, but do not determine, the decision-making process. ${ }^{53}$ Pursuant to that Policy, each disposition must receive a fair return or fair market value. Furthermore, royalties and bonuses are treated as capital moneys within the meaning of the lndion Act.

5.0 Fair Return: Each disposition must give a fair retum. Fair return is a valuc that is wilhin a range that could reasonably be achieved in a competitive market, taking into account the criteria that are unique to the exploration and development of oil and gas on reserve lands.

6.0 Indian Moneys: Pursuant to Section 62 of the Indian $A c \%$, all moneys derived from the sale of oil and gas rights are capital moneys, for example, bonus and royalies. Other moncys are revenuc. such as rents and surface compensation. All such moneys are to be direcled to lOGC.

Without the consent of the band. s. 65 of the Mndicen Act. ibid., provides that the Minister has limiled discretion to pay from capital moncys: (a) compensation (o) an Indian for land expropriated for hand purposes; and (b) to protect the property of Indians in cases of emergency. Indien Act, ibid., s. $6 \mathrm{f}(1)$ : "With the consent of the council of a band, the Minister may authorize and direct the expenditure of revenue moneys for any purpose that in the opinion of the Minister will promole the generail progress and welfare of the band or any member of the bandl." Indian Act, ibid., s. 66(2): e.g. assisting the sick, disabled, aged, etc.; s. $66(3)(c)$ : renowation of premises.

\$1 Ibid.. s. 69: “(1) The Govermor in Council may by order permit a hand to control, manage and expend in whole or in part its revenue moncys and may amend or revoke any such order. (2) The Govemur in Council may make regulations to give effect to subsection (1) and may declare therein the extent to which this Act and the Finconcial Aministration Act shall not apply to a band to which an order made under subsection (1) applies."

$\therefore \quad$ INAC. "Disposition of Oil and Gas Rights Policy" (elfective 22 September 2001), online: INAC <http://www.pgic-ingc.gc.ea/hins/content_page.asp?cid-3-60) | [Disposition Policy|.

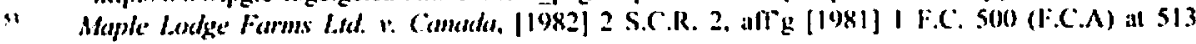
[references omitted]:

The Minister may validly and properly indicate the kind of considerations by which he will be guided as a general rule in the exereise of his discretion, but he cannot fetter his discretion by ireating the guidelines as binding upon him and excluding other valid or relevant reasons for the exercise of his discretion. 
Under the Disposition Policy, 1OGC collects as capital moneys, fair value for bonus ${ }^{5 s}$ and royalty ${ }^{56}$ payments. The IOGC lease or permit is the principal disposition. Given the existence of collateral agreements (for example, carried working interests, ${ }^{\text {s7 }}$ gross overriding royalties, ${ }^{58}$ and lump sum payments), the IOGC requires that the oil companies involved in a proposed deal execute an officer's certificate for disclosure "in writing [of] all agreements collateral to a disposition in which additional consideration is given to the First Nation."59 Only particular types of collateral agreements at fair market value (employment and training, road use, or contracting agreements with the First Nation), may be taken into account in the evaluation of an offer. ${ }^{(x)}$ Once identified, the IOGC may agree to issue a lease if those interests (the collateral agreements) are directed to a band-owned company.

Once the IOGC collects moneys from oil and gas activities on reserve, they are deposited in the CRF and held in trust for the use and benefit of the relevant Indian band. For instance, in Imperial Oil Resources Lud. v. Canada (Minister of Indian Affairs and Northern Developmemt), ${ }^{61}$ Isaac C.J. of the Federal Court of Appeal stated: "It is common ground that the relationship of the Samson Cree Nation and the appellant is that of beneficiary and trustec".62 This trust relationship is not at odds with the fiduciary relationship of Canada to Aboriginals. As stated by the Ontario Court of Appeal in Waxman v. Waxman, ${ }^{63}$ dealing with the doctrines of knowing receipt and knowing assistance:

[I]n this context there is no reason in principle to differentiate between the beneficiary of a trust obligation and the beneficiary of a fiduciary obligation. Both are equally deserving of the protection of equity as against a third party who knowingly assists in the dishonest breach of that obligation or knowingly receives funds paid in breach of it. ${ }^{64}$

ss A bonus is "a premium paid to a grantor or vendor and strictly is the casll consideration or down payment, paid or agreed to be paid, for the execution of an oil and gas Icase": Carroll 1: Bowen, 68 P.2d 773 at 775 (Okla. Sup. Ct. 1937).

The royalty interest generally is the interest retained by the landowner who has entered into an oil and gas lease with the lessee oil company: Howard R. Williams \& Charles J. Meyers, Mamual of Oil cund Gas Terms: Amtotated Mamual oflegal, Engineering, and Tax Words and Phrases, Updated and Revised by Patrick I1. Martin \& Bruce M. Kramer, I0th ed. (New York: Matthew Bender, 1997) at 952.

$\Lambda$ carricd interest arises in a farnoul agreement which is an agreement by one who owns drilling rights to assign all or a portion of those rights to another in return for drilling and testing on the property. It creates a carried interest, an interest whose owner is earricd by others as they pay to drill the well. One parly, as operator, advances all costs of operation and is entilled to recoup these costs only out of operational receipts. The carried party usually contributes all the land or the most valuable land to the agrement. See Sinclair Canada Oil Co. v. Pacific Perroleums L.d., [1969] S.C.R. 394. An overriding royalty (or gross overriding royalty) is a term used to describe an interest carved (severed) from the working interest (lessee's share) of an oil and gas lease (as opposed to the royalty duc to the lessor), free of the expenses of development, operation, and production. See Bank of Montreal v. Dynex Petroleum Lid., 2002 SCC 7, [2002] 1 S.C.R. 146 at para. 2. Disposition Policy, supra note 52 at s. 7.12.

\section{Hid.}

al [1998] 234 N.R. 8.3 (F.C.A.)

6: $\quad$ bid, at para. 7.

(2) (2004), 44 B.L.R. (3d) 165 (Ont. C.A.).

ot hid. at para. 549. See also ibid. at para. 548, referring to Paul Percll. "Intermeddlers or Strangers lo the Breach of Trust or Fiduciary Duly" (1999) 21 Advocates" Q. 94. In Ermineskin Indian Band; Samson Indian Band, supra note 5 at para. 175, a majority of the Federal Court of Appeal agreed with the trial judge that the Crown has met all of its obligations as trustec of the royalties of the Samson and Ermineskin First Nations. 
Once deposited into the CRF interest is credited upon the moneys in accordance with s. 61 (2) and the Orders in Council, ${ }^{\text {s5 }}$ pending payout pursuant to the provisions of the Indian Act.

Fiscally, oil and gas leases on Indian lands tend to be different than provincial Crown or freehold leases. ${ }^{66}$ Until 7 November 2003, the Income $T a x$ Act $f^{77}$ provided for a resource allowance which effectively made Indian royalties deductible when calculating the producer's income for income tax purposes. The resource allowance deduction was phased out over a five-year period: ${ }^{64}$

The resource allowance, which is being repealed under the proposed regulatory changes, provides a deduction to a taxpayer earning resource income in licu of a deduction for Crown royalties and mining taxes. However, the resource allowance does not reflect the actual Crown royaltics and mining taxes bome by the taxpayer. The purpose in repealing the resource allowance and providing a deduction for Crown royalties and mining taxes is to recognize actual costs, thereby treating all resource projects in a comparable fashion. As a result, investment decisions will be based more consistently on the underlying economics of each project. ${ }^{69}$

However, the Indian Resource Council of Canada (IRC) ${ }^{70}$ opposed the climination of the resource allowance, regarding it as an incentive to explore and develop Indian reserve lands. 7

as P.C. 1969-1934, replaced by P.C. 1981-3/255.

cos Stoney Tribal Council v. PanC cuncdion Petroleum, 1998 ABQ13 286. 218 A.R. 201 at para. 26: "Indian gas royalties do not vary depending on the age of production.... IOGC and Alberta have different methods of dealing with gas cost allowances for royallies. In part, this prevents the Indian royaltics from being reduced below a certain level. The Indian royalty rate is much higher than other royalty rates." R.S.C. 1985 (Sth Supp.), c. 1, ss. 12(1)(o), 18(I)(m), as rep. by An Act to Amend the Income Tax Act (Natural Resources), S.C. 2003, c. 28, ss. 1(2). 2(3). nespectively (effective 7 Noventer 2003); Income Tax Regulations, C.R.C., c. 945, s. 1211, as rep. by Regulations Amending the Income Tax Regulations. (Natural Resources), S.O.R./20107-19, s. 6 (cllective I February 2007).

or An Act to Amend the income Tax Act (Natural Resesurces), ibid: Regulations Amending the lancome Tax Regulations (Nutural Resources), ihid.

ew "Regulatory Impact Analysis Stalcment" in Regulations. Amending the Income Tax Regulations (Notural Resources), C. Gaz. 2006.1.2928.

to Created in 1987 and incorporaled in 1996 (Indian Resource Council Inc.) without slare capital under the Canada Business Corporotions ACl, R.S.C. 1985, c. C-44. The IRC is a "I'irst Nation Political Organization": DIAND, Year-end Reporting Ilandbonk for Fint Nations. Tribal Councils and First Nation Political Organizations (November 2003) online: INAC <http://www.ainc-inac.gc.ca/pr/pub/ yrh/yrh01_c.html> at 3.

" Proceedings of the Standing Senate Comminter on Banking. Trade and Commerce. Issue 29-Evidence (30 October 2003) (Roy Fox. President and CEO. Indian Resources Council):

Historically, companies operating on Indian lands have been able to deduct against income the 25 per ecent reseurce allowance, plus royalties paid on lïrst Nations production. Royalties paid on provincial Crown lands have not been deduetible against income. This means that industry hats been able lo achieve higher afler-lax cash llows on Indian lands than on provincial lands. These after-lax cash flows have been used to oflset the additional costs of doing business on Indian lands. These additional costs arise from the need to negotiate cenomic and social benefits with First Nations: collaborating with First Nations on training and cmployment opportunities, and contributing towards community econonic and social development. In other words, the resource allowance and the deductibility of royalties have provided industry with an added incentive to operate on Indian lands. 


\title{
A. Referential Incorporation of Provincial. Laivs
}

Generally speaking, for almost 60 years, Canada has referentially incorporated provisions from provincial oil and gas conservation and environmental law, as contractual terms in federal oil and gas leases on reserves in the respective provinces. The reasons for this referential incorporation practice appear to be driven by concerns for thrift and efficiency, a desire to avoid duplication of governmental resources, and the political desire by both levels of government to share the jurisdiction. For instance, the 1944 lOG Regulations included a new section which required that a lessee comply, as a term of the lease, with the Province of Alberta regulations and legislation on oil and gas conservation, as well as orders of the Conservation Board, should the Minister so direct. ${ }^{\text {? }}$

While the wording of the relevant sections in the various IOG Regulations relating to compliance with provincial legislation has changed from 1944, the role of the Alberta Energy and Utilities Board (AEUB) ${ }^{73}$ and its predecessors has remained more or less the same, that is, regulator of the oil and gas industry in the province, including vital aspects of regulation on reserves. This relationship was commented upon in 1991 by the Auditor Gencral of Canada:

\begin{abstract}
With respect to reliance on the ERCB, we found that $1 O G C$ did not co-ordinate its momitoring practices with those of the Board. It did not assess the ERCB's monitoring plans and reports to determine whether its coverage, methodology and results were adequate for IOGC purposes. IOGC acknowledged that the vast majority of wells in Alberta do not have an Indian band interest and therefore the ERCB's monitoring objectives would have limiled relevance to Indian oil and gas. We noted that it is IOGC's policy to strengthen communications with the LRCB to their mutual benciit."
\end{abstract}

The current provision is found in s. 4(c)of the IOG Regulations (1995):

It is a condition of every contract that the operator will comply with

(a) the applicable provisions of the Indian Act and any applicable orders and regulations made under that Ael:

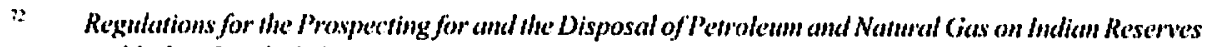
and Indicun Lands, P.C. 5315 (13 July 1944), s. 81:

Where the Minister considers it in the interest of conservation he may direct that the lessee shall comply with any or all of the regulations of the Lieutenant Govemor in Council of the Province of Alberta heretofore or hereafier established under the authority of the Oil and Gas Wells Act, 1942. being Chapter 7 of the Statutes of Alberta, 1942, and any amendments thereto and any or all of the orders of the P'etroleum and Natural Gas Conservation Board constituted pursuant lo the Oil and Gas Resources Conservation Acl being Chapter I of the Statutes of Alberta, 1938 (second session).

3 The Alberta Energy Resources Conservation Board (ERCB) and Alberta Public Utilities Board (PUB) were amalgamated in 1996 to form the Alberta Linergy Utilities Board (AEUB). Efliective I January 2008, the AEUB was realigned into two separate regulatory bodies, the Energy Resources Conservation Board (ERCB), which regulates the energy industry, and the Alberta Utilities Commission (AUC), which regulales the utilities industry.

is Office of the Auditor General of Canada (OAG). 1991 Report of the Auditor General of Canada Chapter 14 - Department of Indian Affairs and Northern Development, online: OAG <hup://www.oagbrg.ge.ca/domino/reports.nsfhtml/9 Imenu_e.html>, s. 14.127 [emphasis added]. 
(b) these Regulations and any dirctions made pursuant theneto; and

(c) unless otherwise agreed to by the Minister and specified in the contract, all provincial laws applicable to non-Indian lands that relate to the enviromment or to the exploration for, or development, treatment, conservation or e'quitable production of, oil and gas and that are not in conflict with the Act or these Regulations.

In particular, the holder of an IOGC lease or permit is required to have a valid provincial well licence before beginning drilling operations: "Before commencing any drilling operations under a permit or lease, an operator shall submit to the band council and to the Executive Director a copy of a well licence or other equivalent document issued by the provincial authority responsible for issuing well licences. ${ }^{* 76}$

For example, in the case of an Indian reserve within Alberta, an operator under an IOGC lease or permit requires a well licence issued pursuant to the Alberta Oil and Gas Conservation $\mathrm{Act}$. ${ }^{\text {Th }}$ This obligation under an IOGC lease or permit requiring an Alberta well licence effectively recognizes that the Alberta OGCA does not apply on its own (ex proprio vigore):

Subject to the terms of any treaty and any other Act of Parliament, all laws of general application from time to time in force in any province are applicable to and in respect of Indians in the province, except to the extent that those laws are inconsistent with this Act or the First Nations Fiscal and Statisrical Managemem Acr or with any order, rule, regulation or laws of a band made under those $A c t s$, and except to the extent that those provincial laws make provision for any matter for which provision is made by or under this Act. ${ }^{7 *}$

The constitutional doctrine of interjurisdictional immunity, however, calls into question the extent of provincial legislative authority on Indian reserves since s. 88 of the Indian ACl, above, only refers to Indians, not lands reserved for Indians. The legislative basis of

3 Supra nole 4. \$. 4 [emphasis added].

i" Ibid., s. I1:s. 2 defines "operator" as "a person who is engaged in an aclivity related to the exploitaltion of oil or gas on Indian lands, including a person who is acting on behalf of, or as an employec or agent of, a contract holder."

$"$ R.S.A. 2000, c. ()-6, s. $4[0(j(-1)]$ :

The purposes of this $A c t$ are

(a) to eflect the conservation of, and to prevent the waste of, the oil and gas resources of Alberta;

(b) to secure the observance of safe and efficient praclices in the locating. spacing, drilling. equipping. constructing, completing, reworking. testing. operating. maintenance, repair. suspension and abandonment of wells and lacilities and in operations for the production of vil and gas;

(c) to provide for the economic, orderly and ellicient development in the public interest of the vil and gas resources of Alberta:

(d) to aflord each owner the opportunity of obtaining the owner's share of the production of oil or gas from any pool:

(c) to provide for the recording and the timely and uselul dissemination of information regurding the oil and gas resources of $A$ lberta:

(1) to control pollution above. at or below the surface in the drilling of wells and in operations for the production of oil and gas and in other operations over which the Board has jurisdiction.

ix Indian. Act, supro note 2. s. 88. 
interjurisdictional immunity is s. 91(24) of the Constitution Act, $1867^{74}$ which grants to Parliament jurisdiction over "Indians, and Lands reserved for the Indians." ${ }^{80}$ Consequently, many provincial laws will have no application at all on s. 91(24) lands unless s. 88 of the Indian Act gives them effect as federal law. For example in $R$. v. Morris, ${ }^{81}$ a majority of the Supreme Court of Canada determined that the appellants' right to hunt at night with an illuminating device was protected under the North Saanich Treaty of 1852 , and that the prohibitions under the British Columbia Wildlife $A \mathrm{Ct}^{82}$ could not be incorporated under s. 88 of the federal Indian Act to be applicable to Aboriginals. ${ }^{3{ }^{3}}$ The minority of the Court stated that the impugned ban on night hunting with a firearm is valid provincial legislation. ${ }^{\text {R. }}$

Accordingly, the applicability of provincial law on reserve is a difficult question because s. 88 of the Indian Act may not include land, and since the distinction made by the courts between activities and land-related matters is not straightforward. Therefore, the provision in s. 4(c) of the IOG Regulations (1995) is a practical solution to a legal conundrum that is not likely to be solved soon absent a legislative solution.

\section{B. SURFACE ACCESS UNDER THE INDIAN OIL AND GAS ACT}

The procedure for entry into Indian reserves, for oil and gas purposes, is laid down in the $1 O G \mathrm{ACt}$ and $1 O G$ Regulations (1995). ${ }^{\mathrm{8S}} \mathrm{A}$ surface rights agreement is ancillary to the arrangements with those awarded resource development rights. It is issued in the form approved by the Executive Director of IOGC. ${ }^{86}$ The IOG Regulations (1995) also provide for the issuance of a survey plan; ${ }^{87}$ the provision of "additional terms and conditions [if] agreed to by the Executive Director, the band council, any band member in lawful possession and the applicant" ${ }^{* x}$ and the payment and periodic renegotiation of surface rent. ${ }^{8 y}$ In the event that negotiations for surface rights rent or compensation cannot be agreed upon, then $\mathbf{s} .30$ of the Regulations provides a mechanism for the Minister to determine the rent or compensation.

The interdependence of subsurface and surface rights is illustrated in s. 28 of the IOG Regulations (1995) by the permissive ability of the Executive Director after deciding to grant a surface lease or right-of-way pursuant to s. 27(4), to "authorize the commencement of

(U.K.), 30 \& 31 Vict., c. 3, reprinted in R.S.C. 1985, App. II, No. 5.

Ibid, s, 91(24).

2006 SCC 59, [2006] 2 S.C.R. 915.

S.B.C. 1982 , c. 57.

Supra note 81 at para. 15.

lbid. at para. 90. McLachlin C.J.C., Bastarache and Fish JJ., dissenting [references omitted]:

Under the doctrine of interjurisdictionul immunity, valid provineial legislation is constitutionally inapplicable to the extent that it intrudes or touches upon core federal legislative competence over a particular matter. Thus, exclusive federal jurisdiction under s. 91(24) protects "core Indianness" from provincial intrusion. Valid provincial legislation which does not touch on "core Indianness" applies ex proprio vigore. If al law does go to "core Indianness" the impugned provincial legislation will mot apply unless it is incorporated into fiederal law by s. 88 of the Indicm Act.

Piche v. Cold Lake Transmission L.dd. (1979), [1980] 2 F.C. 369 (T.D) itl para. 4.

IOG Regulations (1995). stupro note 4, s. 27(1).

Ibid., s. 27(2)(c)(iii).

Ibid., s. 27(4).

thicl., s. 27(6). 
surface operations prior to the issuance of the surface lease or right-of-way." ${ }^{.90}$ Section 31 of the Regulations provides a mechanism for surface rights so that an applicant may enter on reserve land "to locate proposed facilities or conduct surveys or for any other purpose necessary for the completion of an application," permission of the Band Council and any band member in lawful possession. The Regulations also provide a mechanism in the event that an applicant for surface rights requests a right of entry in advance of the granting of a surface lease."

Provision is also made in s. 20 of the $1 O G$ Regulations (1995) for the conversion of permits into a lease. In addition to the express provisions in the regulations concerning surface access, there is a general provision which arguably complements the right of a lessee to enter upon the surface to work the minerals and sever them from the ground: "The holder of a lease may drill for, produce and treat oil and gas within the lease area, transport, market or sell that oil or gas, and carry on such operations as are necessarily incidental thereto."93.

IOGC has a pro forma permit and lease instrument which provides that the conclusion of a Surface Rights Agreement is a condition precedent to the lessec conducting any surface operations. For instance:

4.01 This Lease does not grant surface riglts.

4.02 Prior to conducting any surface operations, including scismic operations, on the Lease Lands. the Lessee shall first obtain all necessary surface rights in accordance with the Indian Oil and Gas Regulations. 1995.

4.03 The Issuance liecs, initial considerations, annual remtals, right of entry fecs and entry fees specified in the Term Sheet shall apply to the surlace rights referred to in clause 4.02.

4.04 Compensation for use by Lessec of Band roads shall be negotiated with and paid to the Band."

Both an IOGC permit and lease make reference to a Surface Rights Agreement which may be terminated by the Executive Director with the approval of the Band Council following cessation of exploration and exploitation operations providing that the lessee or permittee conducts reclamation and abandonment of the well or surface facility. ${ }^{95}$ Since an 1 OGC permit and lease require an operator to have a valid provincial well licence, the relevant provincial requirements concerning the abandonment of any well that is no longer producing (usually by pouring cement down the wellbore), removing all wellhead equipment, and reclamation (returning the land as close to its original state as possible) apply. 


\section{ENVIRONMENTAL. ASSESSMENT UNDER THE INDIAN OL AND GAS ACT}

Under the Canadian Environmental Assessment Act ${ }^{96}$ an environmental assessment (EA) of a project is required before a federal authority exercises certain powers or performs certain duties or functions in respect of a project. ${ }^{97}$ This includes instances where the federal authority "9k "has the administration of federal lands and sells, leases or otherwise disposes of those lands or any interests in those lands ... for the purpose of enabling the project to be carried out." The IOGC is the "federal authority" or "responsible authority" 100 (RA) concerning the environment assessment of oil and gas activities on Indian lands which as mentioned above, are those Indian reserves defined by the Indian Act.

The proposed exercise of certain IOGC powers, duties, or functions, also requires an EA. ${ }^{101}$ These IOGC powers, duties, or functions, pursuant to the IOG Regularions (1995) pertain to: Exploratory Licence, ${ }^{102}$ Surface Rights Lease, ${ }^{103}$ Right of Entry, ${ }^{104}$ Crude Bitumen Lease, ${ }^{105}$ and amendment of Crude Bitumen Permit or Lease. ${ }^{106}$ Therefore, the IOGC, as the RA under the CEAA:

- shall ensure that the EA is "conducted as early as is practicable in the planning stages of the project and before irrevocable decisions are made,"107

- determines "the scope of the project in relation to which an EA is to be conducted," $" 1 / x$

- determines "the scope of the factors to be taken into consideration" in the EA,

- for screenings, where it is "of the opinion that public participation in the screening of a project is appropriate in the circumstances - or where required by regulation," shall provide the public with notice and an opportunity to examine and comment

S.C. 1992, c. 37 [CEAd]

Mid..s. $5(1)$.

Ihid., s. 11 provides that the lederal authority (i.e. IOGC) shall be referred to in this $A \mathrm{ct}$ as the "responsible authority" in relation to the project. Section $2(1)$ provides that "'federal authority" means ... (b) an agency of the Covemment of Canada or other body established by or pursuant to an Act of Parliament that is ultimately accountable through a Minister of the Crown in right of Canada to Parliament for the conduet of its aflitirs." The $C E A d$ contemplates coordination of the environmental assessment process. See Regutations Respecting the Coordination by federal Authorities of Environmental Assessment Procedures and Requirements, S.O.R./97-181.

(EAA, ibid., s. $5(1)(\mathrm{c})$.

Ibid., s. 2(1).

Ibid.. 5. 5(2): CF.AA I.com list Regulutions, S.O.R./94-6.36.

IOC Regulations (1995), sitpro note 4, s. 6(4).

Ibid., s. 27(4).

Ibid., s. $32(1)$.

libid., s. $39(1)$.

Ibid., s. 39(3).

CEAA, supra nole 96 , s. $11(1)$.

Ibid., s. 15(1)(a).

thid., s. $\lg (3)(\mathrm{a})$. 
on the screening report and on any record that has been filed in the public registry, 110

- for comprehensive studies, (necessary for all projects or classes of projects set out in the "comprehensive study list") ensure public consultation complies with required procedures, $"$ "I

- may, for screenings or comprchensive studies, co-operate with other jurisdictions which have the responsibility or an authority to conduct an EA of a project, when there is juridisdictional overlap,"

- shall make a decision on the environmental effects of the project, ${ }^{113}$

- if it makes a decision that the project is unlikely to cause significant adverse environmental effects, the RA shall ensure the implementation of the mitigation measures that it considered in arriving at that decision, ${ }^{114}$ and

- shall design and implement a follow-up program for comprehensive studies and panel reviews, and shall design and implement a follow-up program lor screenings if it considers such a program to be appropriate. ${ }^{115}$

The first phase of an EA is a self-directed assessment through either a screening or a comprehensive study which are considered to be two tracks: "These tracks are considered self-directed because the RA determines the scope of the EA, and directly conducts or manages the EA process in compliance with the requirements of the Act."116

If the sereening concludes that liurther investigatiem is needed, or if public concerns about the project warrant, the RA refers the project to the Minister of the Environment for a referral to mediation or a panel review. In the case of a comprehensive study, the Minster determines whether the project can be referred back to the $\mathrm{RA}$ for action or whether further investigation is required.

No matter which EA track is followed, the goal is to determine whether, alter taking into account the implementation of any miligation measures the $R A$ considers appropriate, the project is likely to result in signilicant adverse environmental effects. Only those environmental eflects as detined in the Act are considered in the determination, which must be supported by objeclive reasoning. based on scientific, technical, and other relewant information. 11 ?

Ibid., s. I8(3).

Ibid., ss. $21(1), 58(1)(i)$ comply with the public participation procedures in ss. $22(1), 21.2$.

Ibid., s. 12(4).

Ibid., ss. 20(1), 37(1).

Bbid., ss. 20(2), 37(2.2).

Ibid., s. 38.

11 Canadian Environmental Assessment Agency (CEAA), The Comudian Envirommemol Assessmem Act: Responsible Auhorin!'s Guide (Hull, Quc.: CEAA. 1994) at 15. 


\section{NEGOTIATIONS WITH FIRST NATIONS LEADING TO THE FIRST NATIONS OHL AND GAS MONEYS MANAGEMENT ACT}

Negotiations concerning the First Nations Oil and Gas Management Pilot Project Initiative ${ }^{118}$ began in 1995 including Canada and each of the five original Pilot First Nations: Blood (Kainaiwa), White Bear, Siksika, Dene Tha', and Horse Lake ${ }^{119}$ (the latter two subsequently withdrew from the Pilot Project). On I April 1998, each pilot First Nation executed an agreement with Canada, the twice amended Enhanced Co-Managemen Agreemen, ${ }^{120}$ setting three stages leading to the goal of full management and control of First Nation oil and gas resources on Indian land. The ECA included provisions for capacity development:

The Minister agrees, subject to appropriations from the Parliament of Canada, to provide funding to the First Nation to carry out their obligations set out under this Agreement. The funding will be provided to the First Nation pursuant to a funding arrangement between the Minister and the First Nation.'

Costs associated with training needs, as identified by the partits to this Agreement. will be an element in the overall funding for the First Nation pursuant to subsection 5.1. ${ }^{\text {1? }}$

The $E C A$ originally contemplated possible conclusion by the parties of an Agreement in Principle (AIP, or AIP on Full Management and Control, or 2.3.3 Agreement) during the first period of the ECA (1 April 1998 - 31 March 2001): "The parties have agreed in principle to the terms of legislation providing for full management and control of oil and gas resources and have completed drafting instructions for the proposed legislation."122

Each pilot band received operational funding, most of which was paid pursuant to an activity-based formula established by IOGC in relation to the oil and gas activity on each pilot band's reserve. The remainder was paid to each pilot band for community consultation, training, and costs incurred in attending meetings.

The ECA was followed by the first Transition Agreement. ${ }^{123}$ A new one-year Transition Agreemem took effect on 1 April 2006 for the purpose of completing the transition of the

Memorandum of Understanding, 1995. [unpublished, archived at DIAND]; for more information, see online: INAC <http://www.pgic-ingc.gc.ca/bins/context_page.asp?'cid=2-468lang=I> [Pilor Project]. The latter two did not fulfill conditions of participation. Henee the remaining three participants are the Blood (Kainaiwa), White Bcar, and Siksika First Nations.

[Unpublished, archived at DIAND] [FCA].

Ibid., s. 5.1, 9.3, respectively. Section II.1 provides that "[o]perations carried out pursuant to this Agrecment will be monitored by IOGC, in cooperation with the First Nation ..." and goes on to incorporale the Enhanced Co-Mencayement Gividelines which are attached to the ECA as Schedule $A$, which includes the provision that: "The First Nations Oil and Gas Pilot l'roject First Nations, for this module, will undertake the following responsibilitics: Controlling and manaing developmental training funding provided to enhance the capacity and knowledge of First Nation administrative staff in associated areas through the attendance training courses provided by industry, IOC;C, or educational institutes."

1:2 $\quad$ bid., s. 2.3.3 [emphasis added].

1:2 [Unpublished. archived at DIAND). 
three pilot First Nations' management and regulatory functions into the FNOGMMA. Thus for over a decade, DIAND and interested pilot First Nations have participated in discussions and negotiations concerning the drafting of Bill C-54 (the proposed FNOGMMA). ${ }^{124}$ During this process of stakeholder involvement, which the Americans call "regulatory negotiation,"12S DIAND regularly provided funding to the proponent First Nations for independent legal advice.

The need for sectoral self-government legislation over First Nations' oil and gas management and related moneys was accentuated, if not accelerated, by the enactment in 1999 of the First Nations Land Management Act. ${ }^{126}$ The FNLMA substantially codifies a 1996 Framework Agreement, ${ }^{127}$ and enables the transfer of reserve land management by the Crown in Right of Canada to a First Nation acceding to that regime, a process that follows bilateral negotjations and the development by the First Nation of a land code. The land code is a governance instrument requiring the approval by a majority of 25 percent of the First Nation's eligible voting members. ${ }^{12 R}$ Powers under the land code, Framework Agreement, and the FNLMA include the ability to:

(a) exercise the powers, rights and privileges of an owner in relation to that land:

(b) grant interests in and licences in relation to that land;

(c) manage the natural resources of that land; and

(d) receive and use all moneys acquired by or on behalf of the first nation under its land code. ${ }^{129}$

However, s. 39(1) of the FNLMA provides that the $1 O G$ Act will continue to apply with respect to: (a) "land that was subject to that Act on the coming into force of the land code" of the relevant First Nation; and (b) "an interest in first nation land that is granted to Her Majesty for the exploitation of oil and gas pursuant to a land code." 31 " This situation would ultimately be addressed by s. 55 of the FNOGMMA which provides that the FNLMA and $I O G$ $A C l$ "do not apply in relation to oil and gas exploration or exploitation in a first nation's managed area as of the first nation's transfer date ${ }^{131}$ accession to the management regime.

Extensive and spirited negotiations led to the enactment of the FNOGMMA, negotiations which took place against the backdrop of far-reaching and complex litigation between various First Nations and Canada over oil and gas resource management and regulation on Indian reserves. Gencrally speaking, oil and gas resource management and regulation on nonIndian Crown land and freehold land is rather complicated. Given the melange of developing

124

An Act to provide first nations with the option of managing and regulating oil and gas exploration and exploitation and of receiving moneys othervise held for them by Canada. I st Sess., 38th Parl., 2005 (as passed by the House of Commons 25 November 2005).

To a very real extent the broad stakeholder involvement and public participation activities that agencies now engage in for virtually every rule or major policy is a result of the success of regulatory negotiation (or "reg neg") and is its direct offspring: see Philip J. Ilarter, "In Search of Goldilocks: Demucracy. Participation, and Government" (2002) 10 Penn. St. Linvtl. L. Rev. 113 at 131.

S.C. 1999, c. 24 [FNLMA]].

[Unpublished, archived at DIAND].

FNL.MA, supra note 126, s. 12(2).

lbid., s. 18(1).

Ibid., s. 39(1)

Supra note 1, s. 55. 
Aboriginal law doctrinc with established precepts of energy law, litigation issues over oil and gas resource management and regulation on Indian reserves may sometimes seem to be more complicated than on non-reserve land. It is somewhat ironic that the FNOGMMA was enacted in November 2005 within a couple of days of the trial decision concerning the first two phases of Samson Indian Band, ${ }^{132}$ which had involved 370 days over the course of nearly five years to present at trial. In the massive trial decision. Teitelbaum J. said:

1 agree that the Crown is a trustec insofar as the Indian moncys at issue in this action are concemed, and that those moneys are trust funds. Even if the ('rown had not admilted the obvious, I would have, in any event, found it to be a truslece.

Because I have found the Crown to be a trustec for Indian moneys and that it may rely on the money management provisions of the Indian Act to carry out its dutics as a trustee, that leads to the conclusion that there can be no unjust curiclument claim.

'Thus, even if 1 am wrong on the enrichment and deprivation elements, the plaintifl's' unjust enrichment claim still lails because valid legislation requires the Crown to deposit the Indian moneys into the CRF pay interest thereon, pursuant to the Orders-in-Council. ${ }^{133}$

In Buffalo, the Samson Cree Nation argued that the Supreme Court of Canada decision in R. v. Sparrow ${ }^{134}$ laid the foundation for the right to self-government over its land and resources. But in that case, Dickson C.I.C. (as he then was) and La Forest J. identified limitations upon constitutional rights, particularly, Aboriginal rights in s. 35(1) of the Constitution Act. 1982. ${ }^{135}$ He set out three questions that must be asked in determining whether there has been a prima facie infringement: (1) Is the limitation unreasonable? (2) Does the regulation impose undue hardship? (3) Does the regulation deny to the holders of the right their preferred means of exercising that right? ${ }^{136}$ In Buffalo, Teitelbaum $\mathrm{J}$. considered Sparrow' and opined that "if the money management provisions of the Indian Act constitute a limitation, they are not unreasonable." ${ }^{37}$ On the second question he opined that that the moneys regulation did not impose undue hardship finding that the "evidence clearly established that Samson has been able to access its capital moneys, and make withdrawals and expenditures." ${ }^{138}$ On the third question, Teitelbaum J. found conflicting objectives, that "the evidence did not show how Samson preferred to manage the money, beyond the

Stupra note 5. The decisions concerned two phases (General and Historical; Money Management) of a multi-phase action and the Court found for the defiendant Canada. Pending a possible appeal to the Supreme Court of Camada, the other phases remained to be tried: Oil and Gus; Other Oil and Gas issues (plaintiffs call it the Tax Issuc; the Crown refers to it as the Regulated Price Regime Issue); and Programs and Services (including Per Capita Distribution Issuc).

Supru note 5 at paras. 653, 710, 726, respectively.

[1990] I S.C.R. 1075 [Sparrou'].

Being Schedule 13 to the Camold det 1982 (U.K.), 198, c. 11.

Sparrow, supra note 134 at para. 70.

Samson Indiwn Btumd, supra note 5 at para. 770.

Ibid. at para. 772. 
confines of this lawsuit, wherein they rely on the experts to argue for what the Crown should have done."139

Another significant case was decided during this long period of negotiation leading to enactment of the FNOGMMA. In Stoney Tribal Council v. PanCanadian Petrolenum LId., ${ }^{\text {(t) }}$ a natural gas producer on the Stoney Indian Reserve was found liable to the plaintiffs (Bearspaw, Chiniki, and Wesley Bands) for the improper deduction of TOPG $A \mathrm{~S}$ (take or pay gas) and $O M A C$ (operating, marketing, and administrative charges). However, the $\Lambda$ lberta Court of Appeal limited the award to six years worth of damages under the applicable provincial limitations law. Although not free from dithiculty as to the basis ol the decision, the result vexed the oil and gas industry which had long been used to the propricty of those deductions on non-Indian Crown land and freehold in Alberta. ${ }^{1+1}$ Pursuant to a comprehensive action in the Federal Court respecting treaty and Aboriginal rights, ${ }^{142}$ and relying upon the decision in Stoney Tribal Council, the same Bands brought motions for summary judgment averring that Canada is responsible for damages for the preceding years (January 1982 to 3 May 1987) and that Canada failed to meet the standard of care applicable to a fiduciary or statutory trustee in the stewardship of the plaintiffs royalties. Thus in Bearspaw Band, the Court found that the issues were appropriate for summary determination in that there would be no genuine issue left for trial. ${ }^{\text {IS }}$ However, the Court also found that neither party put its best foot forward, as each side chose to self-limit to one affiant. Consequently, Gibson J. dismissed the motions for summary judgment with leave to re-apply based on the materials before the Court as supplemented by further evidence. That order was set aside by the Federal Court of Appeal and the motion was adjourned until the parties submitted further and better evidence.

Prior to royal assent on 28 November 2005, the purpose of Bill C-54 (lle proposed FNOGMMA) was summarized during debates in the Senate of Canada:

The goal of this bill is twofold. First, it will provide a comprehensive framework for First Nations lo obtain the complete management and control over oil and gas resources on their reserve lands.

Sccond, it will give First Nations the option to ohtain the complete management and control over monies currently held by Canadia on their hehall, otherwise known as Indian monies. ${ }^{\text {Ht }}$

libid at para. 773.

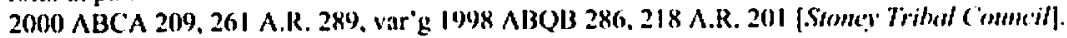
For further discussion of Stome' Tribal Comwil, sec Mungo Hardwicke-Brown et al. "IRecent Developments of Interest to Oil and (ias I.awyers" (2002) 40 Alta. I. Rev. 2IS at 253; Nigel Bankes \& L. Douglas Rac, "Recellt (ases on the Calculation ol Royaltics on First Nations" Lands" (2000) 38 Alta. L. Rev. 258 at 281.

Bearspan Band v. Comoda, 2005 FC 435. rev'd 2007 FCA 39, 361 N.R. 230 [Bearspom Basud]. Ibid. at para. $\mathbf{5 5}$.

Debates of the Se'nute (Hansurd). Ist Sess.. 38th Parl., Vol. 142. Issue 97 (22 Notcmber 2005) (Hon. Rod A. A. Zimmer), moving for sccond reading of lBill C-54. 
The $A c t$ was officially described as "a key step in building stronger and more self-reliant communities," one that "creates a comprehensive regime that will enable participating First Nations to take full control of oil and gas development on their reserve lands."145

\section{Accession to the Oil and Gas Management Regime}

The new Act was proclaimed in force on 1 April 2006. ${ }^{146}$ A number of steps must be taken in order to implement the comprehensive oil and gas management and moneys regimes. In order to begin the process of accession to the oil and gas management and moneys regimes, the council of an Indian reserve anywhere in Canada (exeept in the Yukon ${ }^{1+7}$ ) may submit a written resolution to the Minister respectively requesting accession to those regimes. ${ }^{148}$ Under the FNOGMMA, a qualified discretionary power has been granted by Parliament to the Governor in Council, to issue an order transferring the First Nation into the FNOGMMA oil and gas management regime. ${ }^{149}$ Likewise, a qualified discretionary power has been granted by Parliament to the Minister to issue a Ministerial Order transferring the First Nation into the FNOGMMA moneys regime. ${ }^{150}$

However, certain principal instruments are either required or contemplated before those discretionary decisions may be taken, and before a First Nation may accede to the oil and gas management and moneys regimes. These implementation instruments are distinct from the regulations that may be promulgated by Canada. They include:

- First Nation Oil and Gas Code, s. 10(1);

- Firs Nation Financial Code for Oil and Gas Moneys, s. 10(2);

- Firsı Nasion Oil and Gas Laus, s. 35;

- First Nation Financial Code for Indian Moneys Received from Canada, s. 11;

- First Nation Agreement with Province for Enforcement of First Nation Oil and Gas Laws (a non-mandatory Provincial Agreement), s. 43;

- Canada - First Nation Transfer Agreemen (oil and gas management), s. 15;

- Camada - First Nation Paymen Agreemen (moneys), s. 16; and

- First Nation Trust Agreement (non-mandatory), s. 10(2)(a). ${ }^{\mid s 1}$

INAC, News Release/Communiqué, 2-02745, "Creating Self-Reliant Communities - First Nations Oil and Gas and Moneys Managemen' Act Receives Royal Assent" (28 November 2005), online: INAC $<$ http:/www.aine_inac.gc.ca/nr/prs/s-d2005/2-02745_c.hımls. FNOGWMA, supra note 1.

Ihid., s. 4: "This Act does not apply in respect of reserve lands in the Yukon or in respect of fronticr lands within the meaning of the Canada Perroleum Resources Act."

Ibid., s. 6: council resolution on oil and gas; s. 7: council resolution on montys.

Ibid., s. 22.

Ibid., s. 29.

All sections pursuant to FNOGMAM, supra note 1. 
Once a First Nation has prepared a s. 10(1) Oil and Gas Code and a s. 10(2) Financial Code for Oil and Gas Moneys, then the First Nation and the Minister of DIAND may conclude a Transfer Agreement selting out arrangements for the transfer to the First Nation of the management and regulation of oil and gas: "After a first nation has prepared the codes referred to in section 10 , the Minister and the first nation may conclude a transfer agreement setting out arrangements for the transfer to the first nation of the management and regulation of oil and gas." 152 The Transfer Agreement is a penultimate step before a First Nation may accede to the FNOGMMA oil and gas management regime. For instance, DIAND officials and the pilot bands might seek to develop professional and institutional capacity, goals generally seen by the DIAND as both an important sectoral self-government option and a measurable outcome. ${ }^{153}$ Likewise, once a First Nation has prepared a s. 11 Financial Code for Indian Moneys Received from Canada, then the First Nation and the Minister of DIAND may conclude a s. 16 Payment Agreement setting out arrangements for the payment of moneys to the First Nation.

After the oil and gas Transfer Agreement has been concluded, and after the Payment Agreemen/ has been concluded. then the First Nation may conduct a vote among its membership ${ }^{154}$ secking its approval on whether to accede to the oil and gas management regime, the moneys regime, or both regimes. ${ }^{\text {ss }}$ The purpose of the vote is to seek approval

on the ratification of the oil and gas code and the financial code referred to in section 10 and the approval of the transfer to the first nation of the management and regulation of oil and gas exploration and exploitation.

on the ratificution of the financial code referred to in section II and the approval of the payment of moneys to the first nution in accordance with the eode. ${ }^{15 /}$

A qualified discretionary power has been granted by Parliament to the Governor in Council to issue an Order in Council transferring the First Nation from the current IOG Act regime into the FNOGMMA oil and gas management regime. ${ }^{157}$ In other words, the discretion of the Governor in Council may only be exercised following the preparation of a s. $10(1)$ Oil and Gas Code; a s. 10(2) Financial Code for Oil and Gas Moneys; the making under s. 35 of First Nation laws on exploration and exploitation; the conclusion of a Transfer Agreement; and an affirmative vote by the First Nation's eligible voters. Then the Governor in Council may exercise her discretion with the issuance an Order in Council to add the First Nation's

Jbid., s. 15.

Sec DIAND, Departmental Resul(s-based Monagemen and Accomiability Framework (DRMAF) and Deparmental Risk-Based Audii Fromework (DRBAF) (I February 2006), online: INAC <http:/Www. ainc-inac.gc.ca/pr/pub/rmaf/dm_e.pull> al 91 .

The vote unst be conducled in accordance with the Regularions promulgated pursuant to s. 62(a) of the FNOGilMA. supra note I. The Act identifies who is an eligible voter (s. 20) and the threshold of the majority vole required (s. 21).

lbid., s. 19.

lbid., ss. 17, 18, respectively.

libid, s. 22(1). The transfer date is when the Governor in Council exercises her discretion pursuant to ss. 2, 22 and decides to issue an Order to add the First Nation's name to Schedule $\mathrm{I}$ of the Act. 
name to Schedule I of the $A c t$. This final step transfers authority to the First Nation over the management and regulation of oil and gas exploration and exploitation in all or part of its reserve lands (the managed area). Likewise, a qualified discretionary power, discussed below, has been granted by Parliament to the Minister, to issue a Ministerial Order, transferring the First Nation from the current Indian moneys regime (under the Indian Act and financial Administration $A C$ ) into the FNOGMMA moneys regime. The Act provides for the promulgation of Voting Regulations ${ }^{15 x}$ to ascertain the informed consent of the membership lor entering into the two respective regimes.

\section{A. Prekequisites OF THE Transfer AGRFEMENT}

In order to begin the accession to the oil and gas management and moneys regimes, the council of a First Nation must, pursuant to ss. 6-7 of the FNOGMMA, submit written resolutions to the Minister requesting accession to those respective regimes. For oil and gas management, the FNOGMMA requires that a First Nation must prepare, pursuant to s. 10(1) an Oil and Gas Code, and pursuant to s. 10(2) a Financial Code for Oil and Gas Moneys. Once these Codes are prepared then the First Nation and the Minister may conclude, pursuant to s. 15 of the FNOGMMA, a "transfer agreement setting out arrangements for the transfer to the first nation of the management and regulation of oil and gas."159 The oil and gas exploration and exploitation law-making powers of a First Nation, which are discussed below, are subject to the requirements of its Oil and Gas Code:

Before a vote is conducted on a transler requested under section 6, a first nation shall prepare an oil and gas code that
(a) prescribes the procedure ko be followed by the council of the first nation in the making, annendment and publication of uil and gans laws;
(b) provides for the accountability of the council to lirst nation members for the management and regulation of oil and gas exploration and exploitation: (c) establishes procedures for disclosing and addressing conflicts of interest of members of the council and employees of the first nation in the management and regulation of oil and gas exploration and exploitation;
(d) if the first nation shares a reserve with another first nation. provides for the coordination of the management and regulation of oil and gas exploration and exploitation by the two first nations; and (e) provides for the amendment of the code by the lirst nation. 160

Similarly, the powers to collect oil and gas moneys from contract holders, which are discussed below, are subject to the requirements of the First Nation's Financial Code for Oil and Gas Moneys:

Before a vote is conducted on a translier requested under section 6 , a firsl nation shall prepare a financial code that

First Notions Oil and Gus amd Moners .Managemem Voting Regulotions, S.O.R./2006-0254. Sec also FWOG.MMA, ibid. s. 62(a) [Voring Regulations].

FNOG.lHAL, ibid., s. 15.

Ibid.. s. I0(1). 
(a) specifies the mode of holding oil and gas moneys, either by their deposit in an account with a financial institution or their payment to a trust of which the first nation is settlor and sole beneficiary, and prescribing the conditions governing subsequent changes from one mode to the other;

(b) provides for the manner of collecting oil and gas moneys and the manner of expending moneys held in the account or received by the first nation from the trust:

(c) provides for the accountability of the council to first nation members for the management of oil and gas moncys;

(d) establishes procedures for disclosing and addressing conllicts of interest of members of the council and employees of the lirst nation in the expenditure of those moneys; and

(c) provides for the amendment of the code by the lirst nation. ${ }^{161}$

These Codes are akin to primary legislation, establishing management and accountability limits imposed by the First Nation on the oil and gas exploration and exploitation lawmaking powers of the First Nation Council, which are akin to secondary legislation. When a First Nation accedes to either of the two FNOGMMA regimes, it acquires legal capacity to perform its dutics and hold property. ${ }^{162}$ If a trust is not established to hold oil and gas moneys, ${ }^{163}$ the council of a First Nation must maintain books and accounts, and audited financial statements must be prepared in accordance with generally accepted accounting principles of the Canadian Institute of Chartered Accountants. ${ }^{1 \text { th }}$ Otherwise this obligation rests with the trustees. ${ }^{165}$ Similar management and accountability limits are imposed by the First Nation upon its representatives pursuant to the s. 11 Financial Code for Moneys Received from Canada, although no law-making powers are afforded to the First Nation under that distinct FNOGMMA regime. In addition to these accountability related provisions, the $A c t$ provides transparency by requiring that the audited financial statements from both regimes be made available to First Nations members within four months aller the end of the fiscal year. ${ }^{166}$

Once the Transfer Agreement has been concluded and when the Payment dgreement has been concluded, the First Nation may conduct a vote among its membership ${ }^{167}$ seeking their approval on whether to accede to one of the respective regimes or to both of them. ${ }^{168} \mathrm{~A}$ qualified discretionary power has been granted by Parliament to the Governor in Council, to issue an Order in Council transferring the First Nation from the current $1 O G$ Act regime into the FNOGMMA oil and gas management regime:

The Governor in Council may, by order, add a first nation's nane to Sehedule 1 following

Ibid., s. 10(2).

Ibid., s. 46: "A first nation named in Schedule $I$ or 2 has the legal capacity necessary to exercise its powers and perform its dutics and functions under this $A$ et and. in particular. may acquire and hold property, real or personal and moveable or immoveable, enter into agrecments and be a party to legal proccedings."

lbid.. s. 2(1): "'oil and gas moncys" means moneys derived from sil or gas exploration or exploitation within the managed area of a first nation after the tirst nation's transfer date, and includes fines recovered for offences under oil and gas laws."

Ibid., ss. 48(a), 50(1)

lbid., s. $48(\mathrm{~b})$.

Jbid., s. 50(2).

The vole must be conducted in accordance with the Regulutions promulgated pursuant to s. 62(a). The ACt identifies who is an eligible voter (s. 20) and the threshold of the majority vote required (s. 21).

FNOGIMMA, supra note I. s. 19. 
(a) an aflirmalive votc by the first nation's eligible voters on the ratification of the codes prepared under section 10 and the approval of the transfer of the management and regulation of oil and gas exploration and exploitation to that first nation; and

(b) the making of laws by the council under paragraphs $35(1)$ (a) to (d). ${ }^{169}$

If these prerequisiles are met, then the Governor in Council may exercise her discretion with the issuance of an Order in Council to add the First Nation's name to Schedule I of the $A c t$. This final step transfers authority to the First Nation over the management and regulation of oil and gas exploration and exploitation in all or part of its reserve lands (the Managed Area).

\section{B. OWNership Rights, Law Making Powers, and Responsibilities}

Accession of a First Nation to the FNOGMMA oil and gas management regime will not affect the title of the Crown in Right of Canada to the land in the managed area. However, the rights of Canada and the First Nation that currently exist will be altered once a First Nation opts into the FNOGMMA oil and gas management regime. The First Nation will be invested with rights of an owner with the power to sell rights, to explore for, and exploit oil and gas on the First Nation Lands. For instance:

For greater certainty,

(a) Her Majesty's title to lands in a managed area is not affected by this Act;

(b) lands in a managed area continue to be set apart by Her Majesty for the use and benefit of the first nation for which they were set apart:

(c) lands in a managed area continue to be lands reserved for the Indians within the meaning of Class 24 of section 91 of the Constitution Act. 1867;

(d) this Act does not affect the ability of a first nation to participate in and benefit from any federal government program: and

(c) nothing in this Act shall be construed so as to abrogate or derogate from the protection provided for existing aboriginal or treaty rights of the aboriginal peoples of Canada by the recognition and affirmation of those rights in section 35 of the Constiturion Act. 1982. ${ }^{170}$

Although Crown title to lands in a managed area is not affected by the FNOGMMA, the rights of property in the oil and gas will be affected to the extent that Canada will no longer

Ib/d, s. 3. The Standing Senate Committec on Aboriginal Peoples noted that over the last number of years, a variety of non-derogation clauses have appeared in federal legislation. creating uncertainty and concern for Aboriginal peoples that needs to be resolved. The Commitlee strongly recommends that a thorough study of non-derogation clauses be completed by the Senate Standing Commiltee on Legal and Constitutional Affairs as soon as possible but no later than 30 June 2006: Debales of the Senafe (Hansard). 1st Sess., 38th Parl. (24 November 2005) at 2187 (Hon. Nick (i. Sibbeston). 
be granting oil and gas interests, nor will it be liable for any interests that are granted. Once a First Nation accedes to the FNOGMMA oil and gas management regime, it will no longer have the limited rights formerly ascribed to it as a beneficiary under an $I O G \mathrm{ACl}$ lease. A First Nation will have all the indicia of title and the extensive ability to directly alienate the property in the oil and gas. After all, property is a legally protected expectation of "being able to draw such or such an advantage from the thing [in question], according to the nature of the case." 71 This bundle of rights include the right to exclude, the right to possess, the right to use, the right to dispose of the property, the right to manage the property, and the right to derive income. Accordingly, the rights acquired by a First Nation coincide with the acquisition of the responsibility for stewardship of their oil and gas resources.

The Crown's remaining interest, like the new interest of the First Nation, is a matter involving correlative rights. Most likely, the effect of the FNOGMMA will be similar to the FNLMA ${ }^{172}$ as enunciated in Many Guns v. Siksika Nation Tribal Administration. ${ }^{173}$ In that case, a fire truck belonging to the Siksika National Tribal Administration struck and killed the plaintiff's horse. While the Administration was ultimately found negligent by failing to install a Texas gate, it had unsuccessfully argued that it was statutorily exempt from liability for any such negligence, as the Siksika Nation had not yet approved a land management code pursuant to the FNLMA:

The Defendant submitted that the Crown, meaning either the Minister or the federal government. was the entity that held the legal title to the Siksika Reserve and made the decisions concerning legal dispositions of the Siksika Reserve lands. The Defendant submitted that the federal Crown should have been named as Defendant.

Notwithstanding the holding of legal title by the Crown and the legislative provisions giving the Crown the authority to make legal dispositions of Indian Reserve land, First Nations have a separale legal interest in Indian Reserve land over which they may exercise control. This interest arises independently of the provisions of the Indian Acr. ${ }^{174}$

Therefore, a First Nation under the FNOGMMA oil and gas management regime will have both a discrete legal interest in and extensive power over their oil and gas resources. A at 68 . 
conjunctive reading of oil and gas ${ }^{175}$ and exploitation ${ }^{176}$ indicates authority over oil sands activity, co-generation, ${ }^{177}$ coal bed methane, as well as refinery operation. These value-added activities are widely defined in the FNOGMMA in contrast to the IOG Act, which does not define exploitation. For instance, the legislation would likely apply to the storage of oil and gas in tanks (including refineries) for retail or personal use on reserve, providing that the First Nation Oil and Gas Laws regarding the conservation of oil and gas are not in "conflict with or be inconsistent with the laws of the province applicable to oil and gas exploration and exploitation"178 as required by s. 39 of the FNOGMMA. However, because oil sands activity (other than steam assisted gravity drainage, which permits extraction of bitumen from a well) is a massive industrial undertaking, it is expected that a First Nation will not seek to regulate that activity under the FNOGMMA, but rather by the new First Nations Commercial and Industrial Developmen' $A c t^{179}$ which provides for the establishment of appropriate regulatory regimes to facilitate economic development on First Nations lands.

$\wedge$ First Nation under the FNOGMMA oil and gas management regime will have the "powers, rights and privileges of an owner in relation to oil and gas in the first nation's managed area." 1 "Subject to the requirements of its Oil and Gas Code pursuant to s. 10(1), a First Nation will, in accordance with its oil and gas laws, "manage oil and gas exploration and exploitation in the managed area [and] issue contracts in respect of the managed area"181 and will exercise "the power, in accordance with its financial code, to collect oil and gas moneys from contract holders and to manage and expend those moneys." 182 These powers shall be exercised by the "council of the first nation or by any person, body or government to which the powers are delegated by the first nation's oil and gas laws." ${ }^{83}$ The council of a First Nation "has the power, in accordance with its oil and gas code, to make laws respecting oil and gas exploration and exploitation in the first nation's managed area, to the extent that those laws are not in relation to malters coming within the exclusive jurisdiction of a provincial legislature" ${ }^{" 1 \times 4}$ in particular, powers:

FNOGGMA, stipra nole 1, s. 2(1):

"oil" means any hydrocarbon that can be extracted or recovered in liquid form from surlace or subsurface deposits, other than condensate, or that can be extracted or recovered from bitumen. bituminous sands. oil sands or oil shale...

"gas" means natural gas that can be produced from a well. including natural gas from a coal hed. and includes marketable gass as well as condensate and other fluid components of natural gas that are not oil.

Ibid., s. 2(1): '"exploitation,' in relation to oil or gas, means its extraction, production, storage, distribution. processing or refining. or its use to generate clectrical energy, to the extent that those activities relate to lands in a managed area."

See generally Alexander J. Black. "Llectricity Competition and Fair Markel Access in Canada" (1999) 20 Energy L.J. 291.

FNOGMMA, supra note 1, s. 39.

iw S.C. 2005, c. 53. Section 3(1) provides that "[t]he Governor in Council may make regulations governing commercial or industrial undertakings that are located on reserve lands described in the regulations." Under s. 3(2)(p), a regulation may "exclude the reserve lands or the undertakings from the application of the Indian Oil and Gas Act," a provision which effectively contemplates the industrial seale activity ol oil sands exploitation. See the Forr MfeKan First Nation Oil Sands Regulations, S.O.R./2007-79. FNOGMMA, supre note 1 , s. $34(1)$.

1×1 Jid., s. 34(1)(ai).

18: $\quad$ bid., s. 34(1)(b).

ist Ibid., s. 34(2).

in Ibid., s. 35(1). 
(a) respecting the issuance and the terms and conditions of contracts, including

(i) any fees, rates, rents and royalties, including royalties in kind, to be reserved to the first nation by contract holders.

(ii) the interest payable on amounts owing to the lirst nation under a contract, and

(iii) administrative monetary penalties that may be assessed for lailure to comply with the terms of a contract:

(b) respecting environmenlal assessments of projects in the managed area, and specifying circumstances in which all order may be made prohibiting the proponent of a project from undertaking work before the completion of an environmental assessment:

(c) respecting the protection of the environment from the effects of oil and gas exploration and exploitation in the managed area;

(d) respecting the conservation of oil and gas in the managed area:

(e) establishing offences punishable on summary conviction and imposing fines, imprisonment, restitution and community service for the contravention of oil and gas laws and orders relerred to in paragraph (b);

(f) respecting the inspection. scarch, seizure and delention of property within or outside the managed area for the purpose of ensuring compliance with oil and gas laws and lior the enforcement of those laws: and

(g) respecting the auditing of records of contract holders within or cutside the managed area for the purposes of contract administration. ${ }^{\text {Ixs }}$

The law-making powers of the First Nation are not plenary, but are reasonably qualified. As mentioned, s. 35(1) of the FNOGMMA invalidates any First Nation oil and gas laws that encroach upon exclusive provincial jurisdiction. Certain areas are excluded from the ambit of a First Nation's law-making powers. ${ }^{186}$ While summary criminal procedure is the exclusive mode of prosecution, various specific monetary and imprisonment limitations are imposed upon penalties which may be imposed after a person is convicted of an offence. ${ }^{187}$ Their powers of inspection, scarch, seizure and detention of property prevent the establishment of "procedures inconsistent" ${ }^{\mathrm{Kx}}$ with those of the province where the managed lands are situated, nor can they be "greater than those of a public officer within the meaning of the Criminal

185 Thid., s. 35(1)(a)-(g).

186. Ibid., s. 36 prohibits a First Nation from making laws in relation to

(a) criminal law and criminal procedur:

(b) labour relations, working condilions and occupational health and sulety:

(c) fish and fish habiat. within the meaning of the Fishories Ac\%, migratory birds, within the meaning of the , figratory Birds Combention $A C, 1994$, and spccics at risk, within the meaning of the Species at Risk sit's or

(d) intemational and interprovincial trade, including customs tarifts and export and import controls.

19: Ibid., s. 40.

1kx Ibid., s. 41 . 


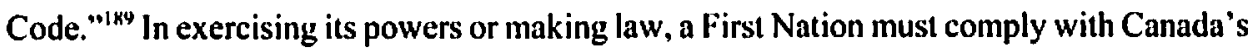
international legal obligations. ${ }^{190}$ Further, First Nation law-making powers are subject to three other main qualifications concerning requirements for an $\mathrm{EA},{ }^{191}$ environmental protection, ${ }^{192}$ as well as oil and gas conservation standards. ${ }^{193}$ These latter qualifications are discussed respectively in the following two sections, below.

Consistent with its ownership rights and law-making powers, a First Nation accepts managerial responsibility when it accedes to the FNOGMMA oil and gas management regime:

27(1) Her Majesty is not liable for

(a) the decision by a first nation or its council to request a transfer under section 6 or for any actions taken by the first nation or its council pursuant to the request;

(b) any loss or dumage resulting from the assignment of contracts to the first nation under section 23; or

(c) an unintentional omission to provide any information referred to in subsection $8(1)$.

(2) Her Majesty is not liable in respect of the exercise of powers by a first nation in relation to oil and gas exploration or exploitation under this Act.

(3) Her Majesty is not liable, as the holder of title to reserve lands or to oil and gas found in those lands, in respect of any damage occasioned by wil and gas exploration or exploitution under this Act. ${ }^{194}$

In other words, ss. 27 and 28 of the FNOGMMA provide for an exclusion of federal Crown liability resulting from a First Nation's accession into the oil and gas management regime and the exercise of oil and gas exploration and exploitation managerial powers by a First Nation. These are statutory exclusion clauses which widely exclude Canada from claims by the relevant First Nation, as well as other persons - a conclusion which is bolstered by the statutory assignment of contracts from Canada to the relevant First Nation under s. 23(1) of the FNOGMMA of all the lessor's rights and obligations in existing contracts in respect of the First Nation's managed area. Subject to the s. 27 exemptions above, s. 28 of the FNOGMMA preserves the liability of the federal Crown "for any act or omission occurring before the first nation's transfer date."195 The practical effect of all these ownership rights, First Nation law-making powers, and exculpatory provisions, is to allocate both the risk and reward of entering into the new regime. 


\section{Statutory ASSignMent of LeASES ANI) SUPERSEdFd DEsignations}

The devolution of oil and gas jurisdiction under the FNOGMMA will involve the transfer (by statutory assignment) of contracts from Canada to the relevant First Nation:

2 (1) "contract" means a licence, permit or lease granting a surface or subsurface right or interest in land or an instrument cvidencing an easement, a right-of-way, al right of entry or any other disposition of a right or interest in land - that is granted, issued or made for the purposes of oil or gas exploration or exploitation.

23(1) On a first nation's transfer dute, the rights and ohligations of lier Mojesty under existing contracts in respect of the first nation's managed area - as well as any agreements reluted to those contracts - are assigned to the first nation.

23(2) The Minister shall provide written notice to contract holders of the assignment of their contracts and any agreements referred to in subsection (1). ${ }^{100}$

When a First Nation accedes to the FNOGMMA oil and gas management regime, then s. 23(1) of the FNOGMMA will operate as a statutory assignment, ${ }^{197}$ transferring from Canada (in its representative capacity as fiduciary and statutory trustee) to the First Nation all the lessor's rights and obligations in existing contracts in respect of the First Nation's managed area. Generally speaking, the effect of an assignment means that the assignee "stands in the shoes" 198 of the assignor, taking her rights and remedies, subject to any defences which the obligor has against the assignor prior to notice of the assignment. In order to perfect the assignment, s. 23(2) of the FNOGMMA states that the Minister must provide written notice to the contract holders ${ }^{199}$ of the assignment. The transfer date is when the Governor in Council exercises her discretion pursuant to ss. 2 and 22 of the FNOGMMA and decides to issue an order to add the First Nation's name to Schedule 1 of the $A c t$. The "managed area" is that part of the lands of the First Nation which are set apart for control by the First Nation as of the transfer date. ${ }^{2(2)}$

Under s. 2(1) of the FNOGMMA, the definition of "contract" is broad enough to apply to contracts to which the lessee is not a party, such as a unitization agreement concerning the

197. For cxample, National Housing Act, R.S.C. 1985, c. N-1 1, s. 8, as an. by S.C. 1999, c. 27, s. 3, was found to be a statutory assignment of all rights in respect to the loan from the approved lender lo Central Mortgage and Housing Corporation: see First Cify Trust Co. v. Jintye (1986), 50 Alta. L.R. (2d) 337 (A.B.Q.13.). At the time of the decision. s. 8 provided that "[a]t the time of conveying the mortgaged property to the Comoralion, any outstanding right to or in respect of the loan or any security therefor shall be transferred to the Corporation."

10x An assignec is clothed in the rights of the cedent (Assignames minur jure anctoris).

144 FNOGMAA, supra note 1, s. 2(1): "'contract' means a licence. pernit or lease granting a surface or subsurface right or interest in land - or an instrument evidencing an casement, a right-of-way, a right of entry or any other disposition of a riglt or interest in land - that is granted, issued or made for the purposes of oil or gas expluration or exploitation."

lbid., ss. 2, 25. 
joint operation of oil and gas leases common to a single-producing reservoir. ${ }^{211}$ In other words, prudent unit operations are part of the fulfillment of all the express or implied obligations of each lease. The words "as well as any agreements related to those contracts" in s. 23(1) of the FNOGMMA, are somewhat redundant and were likely written out of an abundance of caution in order to make sure that all the agreements necessary would be assigned to the relevant First Nation acceding to the FNOGMMA oil and gas management regime. Indeed, the definition of contract found in $\mathrm{s}$. 2(1) of the $A C l$ is broadly defined to include specifically named incidents of land tenure as well as "any other disposition of a right or interest in land - that is granted, issued or made for the purposes of oil or gas exploration or exploitation."

It has been noted that "there is a fiduciary relationship between the federal Crown and the aboriginal peoples of Canada... The nature of the relationship between the parties defines the scope, and the limits, of the dutics that will be imposed."203 However, upon accession to the FNOGMMA oil and gas management regime, the existing designations made to the federal Crown are superseded by the rights and obligations of a First Nation under the new Act:

For greater certainty, after a first nation's transfer dale, any designations made under the /ndian Acr in respect of oil and gas in the lirst nation's managed area cease to have effect, and the rights and obligations of tler Majesty under those designations are superseded by the rights and obligations of the lirst nation under this Act: ${ }^{\text {?M }}$

Thus the powers of the Governor in Council are restricted to within the terms of the FNOGMMA. The Act does not contain a power of revocation for any Order in Council, unlike other legislation. ${ }^{2115}$

Significantly, existing designations are superseded by the rights and obligations of a First Nation under the FNOGMMA oil and gas management regime. This is distinct from the situation under the Indian Act where implied revocation of a surrender or designation is possible. While s. 39(1) of the Indian Act requires a referendum (a solemn formality evidencing informed consent of the band membership) for a band wishing to surrender or designate its land, the $A c t$ is silent about revocation. The fact that the Indian $A c t$ is "entirely

While the terms unitization and pooling are often used interchangeably, unitization represents the joint operation of all or some portion of a producing reservoir, as distinguished from pooling. which term is used to describe the bringing logether of small tracts suflicient for the granting of a well permit under applicable spacing rules. Pooling is important in the prevention of drilling of unnecessary and uneconomic wells, which will result in physical and economic waste. Unitization is important where there is separate ownership of portions of the rights in a common producing pool in order that it may be made economically feasible to engage in cycling. pressure maintenunee, or sccondary recovery operations and to explore for minerals at considerable depth. See Howard R. Williams \& Charles J. Meyers, Mammal of Oil and Gos Torms: Annotated Mommol of Legal, Engineering. and Tax Words and Phrases, Updated and Revised by Patrick H. Martin \& Bruce M. Kramer, 12th ed. (Newark, N.J.: Matthew Bender, 2003).

:w: FNOGMMA, supra note 1, s. 2(1).

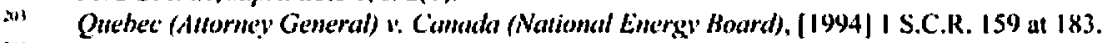

FN FOGMMA, supra note 1, s. 23(3).

sos See, for example, the power of the Governor in Council to onder the revocation of citizenship found in s. 10 of the Cirizenship Act. R.S.C. 1985. c. C-29. 
silent on the subjects of surrender variation, surrender revocation, and re-surrender does not mean that all surrenders are permanent and irrevocable." found to be legal instruments created by a referendum, and the revocation or amendment of an existing surrender or designation was permitted as determined by reference to the band members' intention. ${ }^{207}$

Unlike the regime transition under the FNOGMMA, a surrender or designation under the Indian Act transfers certain rights over Indian land to Canada who is impressed with fiduciary obligations concerning the stewardship of that land. In other words, the Indian Act (as conjunctively read with the $I O G A C$ ) expressly empowers a band to designate Indian lands for oil and gas exploration and exploitation. That legislation impliedly cnables the band (as beneficiary) to revoke the designation (subject to any third party rights). The inverse occurs under the FNOGMMA where any designations made under the Indian $A c t$, are superseded by the rights and obligations of the First Nation under the new Act. While the FNOGMMA affirms the fiduciary relationship, from the date of the accession to the oil and gas management regime, the FNOGMMA enables a re-definition of the scope of Canada's fiduciary obligations that currently exist under the $J O G \mathrm{Act}$.

\section{ENVIRonmental. ASSEssmifnt Reciul.ations}

The council of a First Nation is empowered under s. 35 of the FNOGMMA, subject to its oil and gas code, to make laws respecting oil and gas exploration and exploitation, including the power under s. $35(1)(b)$ to make laws respecting "environmental assessment" concerning any project. ${ }^{20 \%}$ Those laws must meet the content requirements of the First Nations Oil and Gas Environmental Assessment Regulation..2" promulgated by the Governor in Council upon the recommendation of the Minister of the Environment and the Minister of DI $\Lambda$ ND. This qualification on law-making power is both reasonable and necessary because once a First Nation accedes to the FNOGMMA oil and gas management regime, both

Semichtmoo Indian Band v. Canceda (C.A.) (1997). [1998] I F.C. 3 at para. 57, citing Apsassin, supra note 34 at 357, 389-90. For example, in 1988, a de-surrender of oil and gas rights took place by the Rolling River Band in Manitoba.

Apsassin, supra note 34 at para. 6. The majority opinion, written by (jonthier J. using an intention-based approach, found that evidence amply eslablished valid assent by the band members. The minorily opinion, written by MeLachlin J. (as she then was), found thil the evidence did not establish assent by the band members; she noted the need to comply with cerain administrative procedures associated with the resurrender of rescrve lands (i.e. the exccution of a formal revocation document prior to resurrender). FNOGMMA, supra note 1, s. 2(1): "'environmental assessment." in relation to a project in a managed area, means an assessment of the project's effects on the environment conducted in one or more stages in accordanec with a lirst nation's oil and gas laws." Section 2(2) states that "[i]n this $A$ et, "environment"

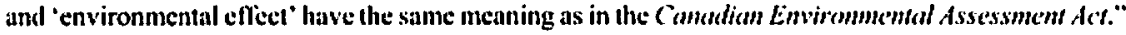
FNOCiMMA, ibid., s. 37. Under s. 2(1), "projece" means:

(a) any proposed construction, operation, modilication, decomunissioning or abandonument of an! installation used for oil or gas exploration or exploitation. or any other proposed undertaking in relation to such an installation; or

(b) any proposed exploration activity of a kind that is defined. by the regulations or by a first nation's oil and gas laws, as a project for the purposes of environmental assessments. 
the $I O G A C t$ and the $F N L M A^{211}$ cease to apply in relation to oil and gas exploitation on the First Nation's managed area. ${ }^{212}$

Once a First Nation accedes to the FNOGMMA oil and gas management regime, then neither IOGC nor the First Nation will be a federal RA under the CEAA. This eventuality accounts for the ability of the Govemor in Council to make regulations pursuant to s. 63 of the FNOGMMA, to grandfather federal EA standards by conditioning the content of First Nation Oil and Gas Laws in relation to the EA of a project. According to s. 63(3) of the FNOGMMA, the requirements of these regulations "must be generally comparable with those applicable in similar circumstances under the Canadian Environmental Assessment Act."213 In this way, the standards of the CEAA are grandfathered into the FNOGMMA. Depending upon the precision of the FNOGEA Regulations pursuant to s. 63 of the FNOGMMA, generally comparable standards may be tantamount to the actual $C E A A$ standards currently applied in regards to oil and gas activities on Indian reserves under the $I O G \mathrm{Act}^{214}$

These generally comparable CEAA standards under s. 63(3) of the FNOGMMA will percolate into First Nation Oil and Gas Laws because s. 56 of the FNOGMMA provides that in the event of a conflict between a First Nation's oil and gas laws and federal laws regarding EA, the federal laws prevail. Hence, it is too wide a statement to say that the CEAA absolutely does not apply after the transfer date when a First Nation accedes to the FNOGMMA oil and gas management regime. There will be ongoing federal EA obligations on Indian reserves for activities other than FNOGMMA-related oil and gas management activities. For example, if a First Nation has not acceded to or has not promulgated a land Code under the $F N L M A,{ }^{215}$ then the $C E A A$ would apply to the land activities contemplated by the former statute. Even if a First Nation has promulgated a land code under the FNLMA, oil and gas activities on designated land continue to be entirely governed by the $1 O G \mathrm{Act},{ }^{216}$

211 Supra note 126.

12 FNOGMMA, supra note 1, s. 55. The FNI,MA and the $1 O G$ Act do not apply in relation to oil and gas exploration or exploitation in a First Nation's managed area as of the first nation's transfer date.

213 Ihid., s. 63(3). Section $37(1)$ of the FNOGMMA outlines the projects to be subject to an EA:

A first nation's oil and gas laws must provide that no project. unless exempled by regulations made under subsection 63(2). may be undertaken until an environmental assessment of it has been conducted under those laws and every decision-making authority for the project has taken the results of the assessment into account in making any decision that would enable the project to be undertaken.

Section 37(2) states that "|t|he content of laws respecting environmental assessments of projects must conform with regulations made under s. 63(1)."

:14 See also $C E A A$, supra note 96, s. 10, which provides for assessments by Band Councils under the $C E A A$ regulations.

21s Under s. 12(1) of the FNLMA, supra note 126, the transfer of reserve land management by the Crown in Right of Canada to a First Nation, follows bilateral negotiations and the development by the First Nation of a land code. The land code is a governance instrument requiring the approval by a majority of at least 25 percent of the First Nation's cligible voling members (s. 12(2)). Section 18(1) powers under the land code. Framework Agreement, and the FNL.MA, include the ubility to: "(a) ... excreise the powers, rights and privileges of an owner in relation to that land; (b) ... grant interests in and licences in relation to that land: (c) manage the natural resources ol that land; and (d) receive and use all moneys acyuired by or on behalf of the first nation under its land code."

216 FNLMA, ibid., s. 39(1)(a). The $1 O G$ ACt will continue to apply with respect to "(a) ...lund that was subject to that Act on the coming into force of the land code of the relevant first nation, and (b) ....an interest in first nation land that is granted to Her Majesty for the exploitation of oil and gas pursuant to a land code." 
with EAs directly prescribed by the $C E A A$ until such time as a First Nation accedes to the FNOGMMA oil and gas management regime. Even if a First Nation accedes to the FNOGMMA oil and gas management regime, the CEAA will continue to apply to the actions of federal authorities (other than the IOGC) regarding oil and gas projects on reserve. For example, if the DIAND provides any funding to the project, then the DIAND will be triggered under s. $5(1)(\mathrm{b})$ of the $C E A A$. Another example is if the proponent requires an authorization under s. 35(2) of the Fisheries $A \mathrm{Cl}^{217}$ the Department of Fisheries and Oceans will be an RA and have to ensure the conduct of an EA under the CEAA.

Since the FNOGEA Regulations have been promulgated as of 29 November $2007,,^{218}$ it is likely that the CEAA will liaise with First Nations which accede to the FNOGMMA oil and gas management regime. One of the objects of that agency is to promote uniformity and harmonization in the assessment of environmental effects across Canada at all levels of government. ${ }^{219}$ Furthermore, the CEAA is enjoined to co-operate with other jurisdictions, which include "a governing body that is established pursuant to legislation that relates to the self-government of Indians and that has powers, duties or functions in relation to an assessment of the environmental effects of a project. "221" This definition of jurisdiction would apparently include the council of a First Nation under the FNOGMMA. Generally speaking, it is likely that other departments of the federal government may liaise with councils of First Nations (Indian bands within the meaning the Indian Act) under the FNOGMMA, legislation aimed at sectoral self-government of oil and gas activity on the land (or reserve) of a First Nation. After all, "[d]evolution is not divorce. The process involves a loosening of the bonds."221

\section{E. Environmental Protection and Oll, and Gas Conservation}

First Nation law-making powers are also subject to qualifications concerning requirements for environmental protection, ${ }^{222}$ as well as oil and gas conservation standards. ${ }^{223}$ These qualifications on law-making power are both reasonable and necessary because the requirements and standards of the province have historically been incorporated by reference into federal oil and gas leases on reserves within a respective province. ${ }^{22-1}$ For instance, the standard required of an operator is invariably in accordance with good oillield practices, ${ }^{225}$ a standard pertaining to oil and gas exploration and exploitation which is akin to the broader "reasonable person" test in tort law. This qualification on law-making power recognizes

R.S.C. 1985 , c. F-14.

Supra note 210.

CEAA, supra note 96, ss. 61(1), 62(b).

lbid., s. 12(5)(d).

Richard Rawlings, "Concordats of the Constitution" (2000) I 16 Law Q. Rev. 257 at 262.

FNOGMMA, supra note 1. s. 38. Sec First Nation Oil and Gas Environmental Assessmem Regutations, S.O.R./2007.272.

Ibid., s. 39.

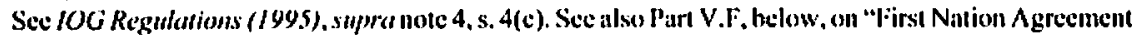
with Provinee and Referential Incorporation ol Law."

See Camadian Association of Petroleum Landmen, Operoting Procedure (Calgary: The Association. 1990) at 7, cl. 304: "The operator shall conduct all joint operations diligently, in a good and workmanlike manner, in accordance with good oillicld practice and the Regulations": Morgan v. Sunray" Perroleum Corp. (N.P.I.) (No. 2), [1941] 2 W.W.R. 603 (Alta. S.C.(T.D)), alTd [1942] 2 W.W.R. 53 (Alta. S.C. (A.D.)), concerning gond drilling practices. 
harmonization with the benchmark nature of the relevant provincial standards for environmental protection and conservation standards as they pertain to oil and gas exploration and exploitation:

Subject to the regulations, oil and gas laws must provide protection for the environment that is at least equal to that provided by the laws of the provinee applicable to oil and gas exploration and exploitation.

Subject to the regulations, oil and gas laws with respect to the conservation of oil and gas must not conllict with or be inconsistent with the laws of the province applicable to oil and gas exploration and exploitation. 220

Section 62 of the FNOGMMA empowers the Governor in Council to promulgate environmental protection regulations as well as oil and gas conservation regulations:

(c) setting the minimal requirements ol'oil and gas laws made in relation to the protection of the environment, including by the incorporation by reference of provincial laws as anended from time to time:

(d) setting the minimal requirements of oil and gas laws made in relation to the conservation of oil and gas. including by the incorporation by reference of provincial laws as amended from time to lime; and

(c) in the absence of an agreement with the government of a province referred to in section 43, establishing bodies, or designating existing bodies, 10 administer oil and gas laws that incorporate laws of the provinec. ${ }^{227}$

In order to elicit public comment, a draft of the FNOGEA Regulations was pre-published in the Canada Gazette on 26 May 2007.228

There are two ways in which these standards may be met, an alternative dependent on

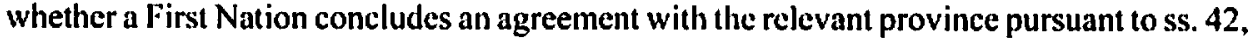
43 of the FNOGMMA. This so-called Provincial Agreement is discussed in the following section. Since the respective provincial authorities currently provide oil and gas regulatory services to operations pursuant to an IOG ACt permit or lease, the conclusion of a Provincial Agreement has the virtue of continuing a relatively efficient form of resource stewardship. In the absence of such a Provincial Agreement, then the regulation-making power granted to the Governor in Council contemplates the complicated process of promulgation of regulations setting minimum requirements of First Nation Oil and Gas Laws concerning the areas of environmental protection and resource conservation. Also, in the absence of a Provincial Agreement, s. 62(c) of the FNOGMMA effectively requires the creation or designation of a body to administer those Firsı Nation Oil and Gas Laws that incorporate laws of the province. 


\section{F. First Nation Agreenext with Province A.Nd REFERENTIAL INCORPORATION OF LAW}

Provincial standards on environmental protection and resource conservation, as mentioned above, will continue to apply to a First Nation acceding to the FNOGMMA oil and gas management regime. The need for these provincial standards is a continuation of the historical interface of provincial regulatory services concerning oil and gas activities on reserve. Recently, a series of industrial development proposals have been put forward by various First Nations requiring the need for the on-reserve regulation of oilsands exploitation. gas condensate refinery operation, electricity co-generation, etc. The paradigm has shifted from the mere extraction of oil and gas on reserve into broader activities aimed at eliciting economic development.

As mentioned above, for over 60 years, under the current $I O G$ ACt and its statutory predecessors, Canada has referentially incorporated provincial oil and gas conservation and environmental law into federal oil and gas leases on reserves within a respective province. The current instrument for incorporation of provincial laws on the environment and oil and gas conservation into an IOGC lease is s. 4(c) of the IOG Regularions (1995):

It is a condition of every contract that the operator will comply with

(a) the applicable provisions of the Indien Act and any applicable orders and regulations made under lhat Act:

(b) these Regulations and any directions made purstant thereto: ${ }^{221}$ and

(c) unless otherwise agreed to by the Minister and specified in the contract, all provincial laws applicable to non-Indian lands that relate to the coxvironment" or to the exploration for, or dev elopment. treatment. conservation or equitable production ol, oil and gas and that are not in conflict with the Act or these Regulations. 231

The reasons for this practice appcar to be driven by concerns for thrift and efficiency, a desire to avoid duplication of governmental resources, and the political desire by both levels of government to share authority. Thus the provinees of $\Lambda$ lberta and Saskaltelewan have respectively provided regulatory services to parties in an IOGC lease. ${ }^{32}$

Under the FNOGMMA, a Provincial Agreemen' (an agreement between the First Nation and the Government of the relevant province) is one of two ways a First Nation may

This is the well-known technique of referential incomoration. This allows the IOCIC lo enforee the Regulations under administrative law, or alternatively, under private law since the Regulations are conditions of the contract. Sec generally Alexander J. Black. "Comparative l.icensing Aspects of" Canadian and United Kingdom Istroleum Law" (1986) 21 Tex. Int'I L.J. 471 at 472-8.4. Although the word "provincial" is used, the IOCiC has concurrent obligations under the (FAt. IOG Regulations (1995), supra note 4, s. 4(a)-(c).

These services include: well licensing. Well spacing, unitization and pooling. prevention of waste, setting of allowables, oilficld safety, common processor/common transportation. cnhanced recovery; and gencral provincial regulatory staff expertise. 
implement the FNOGMMA oil and gas management regime. Such a Provincial Agreement is needed in the absence of the promulgation of regulations by the Governor in Council setting minimum requirements of First Nation Oil and Gas Laws concerning the areas of environmental protection and resource conservation. The purpose of the Provincial Agreement is to arrange the use of provincial regulatory services to enforce First Nation Oil and Gas Laws. During the Parliamentary Debates preceding the passing of the $\mathrm{Act}$, the province of Alberta expressed support for this regulatory approach. ${ }^{233}$ Before a First Nation might reasonably expect to conclude a Provincial Agreement, it must incorporate by reference into its First Nation Oil and Gas Laws, laws of the relevant province on environmental protection and conservation regulations concerning oil and gas exploration and exploitation. The ability of the provincial authority to administer and enforce any referentially incorporated provincial law, however, will depend upon the Provincial Agreement pursuant to ss. 42 and 43 of the FNOGMMA:

Oil and gas laws may incorporate by reference laws of the province in which the managed area is located as they are amended from time to time.

An oil and gas law may, in accordance with an agreement between a first nation and the government of the province in which its managed area is localed.

(a) specify the respective responsibilities of the first nation and the province for the administration and enforcement of oil and gas laws; and

(b) provide for access by officers of the first nation and the province, respectively, to the managed arca for the enforcement of oil and gas laws. ${ }^{234}$

\section{G. ACCession to the Moneys Regime}

Once under the new management regime, a First Nation will directly receive its revenues from oil and gas activities and will manage it according to its s. 10(2) Financial Code for Oil and Gas Moneys. Any First Nation may seek to accede (by being named in Schedule 2) to the FNOGMMA regime concerning the First Nations' moneys held (or receivable) by Her

Debales of the Senate (Hansard), supra nole 144: The Hon. Rod A.A. Limmer went on to say that [1]he assistant depuly minister for land and resource issues in the Albera Department of Aboriginal Affairs and Northern Development, Neil Reddekopp, supports this regulatory approach. In testifying before the Standing Conmittec on Aboriginal Affairs and Northem Development in the other place, he said that First Nations:

...may enter into agreements with the provinces to provide for regulation of these matcers by provincial bodies and oflicials in a similar manner to what is applied to same issues off reserve.

Based on these discussions over the past several years, it appears that all three partnering First Nations plan to avail themselves of this oppontunity... This decision is worthy of considerable praise for its wisdom. 
Majesty, or both those purposes. ${ }^{235}$ This option may be exercised by itself or in conjunction with the option to accede to the FNOGMMA oil and gas management regime:

The council of a lirst nation may submit to the Minister a written resolution of the council requesting the payment to the first nation of

(a) moneys held by Her Majesty for the use and benefit of the first nation: and

(b) moneys to be collected or received in future by ller Majesty for the use and bencfil of the first nation. 236

This provision impliedly refers to all moneys (both capital and revenue) which Canada collects and holds in trust for the benefit of the respective First Nations. Most of the money is capital moneys held by Canada pertaining to royalties and bonuses stemming from oil and gas activities authorized by the $I O G A C t$, although some moneys pertain to renewable natural resources like timber. Before availing itself of this regime and receiving its Indian moneys held in trust by Canada, the First Nation must prepare a Financial Code for Moneys Received from Canada pursuant to s. 11 of the FNOGMMA. That Code imposes management and accountability limits upon the representatives of the First Nation in their handling of those moneys:

Belore a vole is conducted on a payment requested under section 7, a first nation shall prepare a financial code

(a) specifying the mode of holding moneys paid by Her Majesty to the first nation under sections 30 and 31 by their deposit in an account with a financial institution or payment to a trust of which the first nation is settlor and sole beneliciary, and prescribing the conditions governing future changes from one mode to the other:

(b) respecting the manner of expending moneys held by the first nation in the account or received by it from the trust;

(c) respecting the accountability of the council of the first nation to lirst nattion members fior the expenditure of those moneys:

(d) establishing procedures for diselosing and addressing conllicts of interest of members of the council and employess of the lirst nation in the expenditure of those moneys; and

(c) providing for the amendment of the code by the first nation. ${ }^{237}$ and decides to issue an order 10 add the First Nation's name to Sch. 2 of the Act. For instance. undet FNOG,IMA, ibid., s. 11 , the First Nation is required to prepare a Financial Code for Moneys Recerived from Comada. This code is also a govemance instrument which needs to be ratified by an altimative vole of the First Nation's eligible voters pursuant to s. 29 of the $A c$, who must also approve the payment of moneys to the First Nation in accordance with the Code.

lbid., s. 11 . 
Upon the preparation of a Financial Code for Indian Moneys Received from Camada, the First Nation is empowered to enter in an agreement with the Minister of the DIAND to conclude a Payment Agreement, pursuant to s. 16 of the FNOGMMA, setting out arrangements for the payment of moneys to the First Nation. Section 18 of the Act then empowers the First Nation to conduct a vote among its membership seeking their approval on whether to accede to the moncys regime. A qualified discretionary power has been granted by Parliament to the Minister, to issue a Ministerial Order, the effect of which is to transfer the First Nation from the current Indian moneys regime (under the Indion Act and Financial A(ministration $A c t)$ into the FNOGMMA moneys regime: "The Minister may, by order, add a first nation's name to Schedule 2 following an affirmative vote of the first nation's eligible voters on the ratification of the code prepared under section 11 and the approval of the payment of moneys to the first nation in accordance with the code." 238

If these prerequisites are met then the Minister may exercise his discretion with the issuance an Order to add the First Nation's name to Schedule 2 of the Act. This step triggers the payment of Indian moneys (held by Canada for the benefit of the First Nation) under the aegis of the Payment Agreement, to the First Nation absolutely, in accordance with its Financial Code for Moneys Received from Canada. Concerning an initial payment ${ }^{239}$ to the First Nation and any subsequent payments, ${ }^{2+11}$ if an account is established to hold moneys received from Canada, the council of a First Nation must maintain books and accounts and audited financial statements must be prepared "in accordance with the generally accepted accounting principles of the Canadian Institute of Chartered Accountants." $2+1$ If a trust is established, then this obligation (for maintaining books of accounts and obtaining audited financial statements) rests with the trustees and the council of the First Nation. ${ }^{242}$

Members of a First Nation council may serve as trustees in their personal capacity. ${ }^{2+3}$ The council of a First Nation may require security from a trustec who is not a trust company. ${ }^{244}$ Any trust created by a First Nation under the FNOGMMA management or moneys regimes, is subject to the "[l]aws of general application in relation to trusts and trustees in force in the province in which the trust instrument is executed."245 The FNOGMMA provides that such a trust is exempt from the application of the rule against perpetuitics and accumulations. ${ }^{246}$ In the 18th century, the fact that executory interests were made indestructible in equity ${ }^{247}$ elicited the rule against perpetuities, a judicial response made to control executory interests.

\footnotetext{
23x Ihid., s. 29(1).

its Hid., s. 30.

(11) Hid., s. 31

241 Thid., s. 49(a).

a. lbid., s. 49(b).

: lit. 5.13.

iH Thid., s. 14.

ass Ibid., s. $12(1)$.

2th Hid., s. 12(2). Another reason why the rule against perpetuitics may not apply concerns the status of reserve land which is held by Her Majesty for the use and bencfil of the liirst Nation. All members are to share during their lifetime in this use and benefit. Assuming the reserve is held for generations, the objective of the reserve and the manner by which it and the liruits from the reserve land (money) is to he managel under the Indian Act may be inconsistent with the rule against perpetuitics. This may be one of those situalions referred to in St. Mary's Indian Band '. Crambrook (City of), [1997] 2 S.C.R. 678, where the common law principles do not or should not apply. 
The rule against perpetuities prevents the use of certain executory agreements in settlements which would prevent the alienation of land for an unreasonable period of time. It is distinguished from the rule against restraints on alienation. ${ }^{248}$ Given the collective entitlement of First Nations members to their oil and gas revenues, it makes sense to exempt a FNOGMMA trust from the application of the rule against perpetuities. After all, that doctrine is a "technicality ridden legal nightmare, ... a dangerous instrumentality in the hands of most members of the bar."2s9

A parallel exists between this legislative mechanism for Indian moneys received from Canada and the judicial mechanism in an carlier decision of Samson Indian Nasion and Band v. Canada, ${ }^{250}$ where an interlocutory order was issued setting out several conditions that needed to be fulfilled by the Samson Cree Nation before a transfer could occur of approximately CDN\$360 million in capital moneys which were held by the Crown. A referendum of the band membership must be held where a majority must be in favour of receiving the money. An external and independent trustee for the money may be appointed to receive and handle the money pursuant to a trust agreement which must be approved by the Court, including the conditions necessary for the payout of income and encroachments upon capital. Future capital monies paid to the Crown for the benefit of Samson Cree Nation shall be transferred to the trust in accordance with subsequent agreements between Samson Cree Nation and the Crown, or failing agreement, as determined by the Court: ${ }^{2 s t}$

Samson must also release the Crown from any future liability for the capital monies (existing or future) or for their sale custody, management, preservation of capital and rate of retum, once the funds are transferred to the Irust, such release being applicable and remaining valid regardless of whether any sections of the Indian Act are subsequently declared unconstitutional. ${ }^{292}$

The trust agreement, liability release, and referendum results must be attached to a Band Council resolution addressed to the Minister requesting the transfer, "except for the sum of

The rule against restraints on alienation rellects the right of unrestricted alienation of fee simple estates. In Laurin v. Iron Ore Co. of Comuda (1977), 19 NIld. \& P.E.I.R. 111 (S.C.(I.I).)) at 130. Goodridge, J. said:

The law on the subject is well stated by Cheshire. Modem Real Property, (9th Ldition), at 286. which reads as lollows:

"In accordance with the cardinal principle that the power of" inlienation is necessarily and inseparably incidental to ownership it has been held in a long line of decisions that if an absolute interest is given to a donee - whether it be a fee simple, a fee interest, and whether it be in possession or in future - any restriction which substantially takes that power away is woid as being repugnant to the very conception of ownership. Thereforc, a condition that the donee ... shall alienate only to one particular person ... is void."

The continued existence of the rule and its development over the years is probably based on public policy more than the statule. In the case of Sicphens v. Gulf Oil Camodes Limited (1975), 11 O.R. (2d)

129) at page 156, Howland J.A. said:

"The objections in principle lo restraints on alienation are twolold. They kecp property out of conmeree and have a lendency to result in a concentration of wealth. They also tend to prevent improvement of property, since a landowner will be reluctant lo make improvenents when he cannot sell the property." 
$\$ 3$ million which will be held back to resolve any outstanding issues." "ss3 Upon the fulfillment of these conditions, the Minister would then "authorize the transfer of Samson's existing and future capital moneys to the agreed upon trust pursuant to paragraph $64(1)(\mathrm{k})$ of the Indian Act."254

Like the effect of accession to the oil and gas management regime, the FNOGMMA also provides for an exclusion of federal Crown liability resulting from a First Nation's accession into the moneys regime. Section 32 of the $\mathrm{Act}$ is a statutory exclusion clause protecting Canada from claims by the relevant First Nation, as well as other persons, concerning liability for payment of moneys out of the CRF and the future management of those moneys:

$32(1)$ Her Majesty is not liable for the decision by a first nation or its council to request a payment under section 7 or for any actions taken by the first nation or its council pursuant to the request.

(2) Following the payment of moneys out of the Consolidated Revenue Fund into an account or a trust under section 30 or 31 . 1ler Majesty is not liable for the payment or the management of those moneys. ${ }^{255}$

These exculpatory provisions in favour of the federal Crown complement the acceptance of responsibility by a First Nation for the stewardship of its moneys after their remittance from the federal Crown. These provisions are similar to those mentioned above concerning the accession to the oil and gas management regime. Section 33 of the $\mathrm{Act}$ preserves the liability of the federal Crown or a First Nation "for any act or omission in respect of moneys occurring before a payment referred to in subsection 32(2)."

\section{H. Depleting ASSETS AND FIRSt Nations' Business ACUMEN}

A First Nation under the FNOGMMA oil and gas management regime will have the "powers, rights and privileges of an owner in relation to oil and gas in the first nation's managed area," ${ }^{257}$ including

the power, in accordance with its oil and gas laws, to manage oil and gas exploration and exploitation in the managed area and to issue contracts in respect of the managed area; and

the power, in accordance with its financial code, to collect oil and gas moneys from contract holders and to manage and expend those moneys. $25 x$

These powers are a logical progression from the $1 O G \mathrm{ACt}$. For instance, during the Parliamentary debates in 1974 prior to the $/ O G \mathrm{Act}$, the Minister of Indian Affairs and Northern Development, the Honourable Judd Buchanan said:

thid. at para 9.

Ibid.

FNOGMMA, supra note 1, s. 32(1).

thid., s. 33.

Ibid., s. 34(1).

Ibid., ss. 34 (1)(a)(b). 
All of us are aware how essential it is for Indian bands and people to participate fully in the Canadian economy, getting all the benefits they can from the lands set aside on their behalf. This bill is intended to ensure that equitable benefits from oil and gas production on Indian lands go to the Indian people. ${ }^{259}$

Over the years, many First Nations have effectively become sophisticated sellers of their oil and gas, a non-renewable natural resource which is a wasting or depleting asset:

In oil and gas, the recoverable reserves will run out over the life of the program. Thus, there is generally no residual or back-end to the investment, as compared to un investment in real estate where you expect a return of principal and perhaps a big profit al the time that the asset is sold. Even in equipment leasing, the assets are expected to retain some residual value. ${ }^{260}$

Oil and gas leases represent only the right to explore and extract minerals during a fixed and relatively short period of time (customarily three to five years). If the lease period expires without development being commenced, the lease becomes worthless. Firthermore, lluctuations in the value of oil and gats eollateral tend to be multiplied in comparison with changes in current energy prices because the value of the collaleral depends on analysis of an uncertain future income stream. ${ }^{261}$

Accordingly, the earliest income tax acts recognized that a portion of production income should be attributed to the depletion of reserves. In other words, the depletion allowance recognizes that "mineral deposits are wasting assets..." and permits "a recoupment of the owner's capital investment in the minerals so that when the minerals are exhausted. the owner's capital is unimpaired." ${ }^{-262}$

A First Nation under the FNOGMMA may possibly avail itself of innovative business structures. As discussed below, a First Nation may request and possibly receive an advanced tax ruling from the Canada Revenue Agency (CRA), exempting it from income taxation on all oil and gas moneys and Indian moneys received under the FNOGMMA regime. Consequently a First Nation could possibly leverage itself creatively, for example, allocating

35" House of Commons Dehates, Ist Sess., 30th Parl. (21 October 1974) at 557-58 (Hun. Judd Buchanan).

2n) Robert J. Hatt \& Peter M. Fass. Tax-Adrantaged Securities: II.Ps. Pass-Thronghs. and Other Iehicles. 4th ed. (St. Paul, Minn.: West Group,1981), c. 7.

:61 Harrell \& Dancy, "Unstable Crude Oil Prices and Their Effect On Producers and Financial Institutions." in Mitsuru Miyata \& Kenich Matsui, eds., Energy Decisions for the Firme, Challenges and Opporfumities, Proceedings of the 8th Annual International Conlerence. International Association of Energy Economists Honouring the $20 \mathrm{~h}$ Anniversary of the Institute of Lnergy Economies, Japan. Tokyo, June 1986 (Washington. D.C.: IALE 1986).

:6: Helvering v. Bankline Oil Co., 303 U.S. 362 at 366 (1938): Commissioner v. Somthucest Explewation Co., 350 U.S. 308 at 312 (1956), respectively. Owen L. Anderson. "Royalty Valuation: Should Royalty Obligations Bo Determined Intrinsically. Theonetically, or Realistically?" (1997) 37 Nat. Resources J. 547 at 553-54: "['T] hanks to the general availability of the percentege depletion allowance and a gencral desire to discourage competition in refining and marketing, the integrated oil and gas industry had both a tax and an economic incentive to push profits upstream toward the wellhead and push costs downstream auray from the wellhead." 
for value its unused depletion allowances ${ }^{263}$ to limited partners who are subject to income taxation. ${ }^{2 n-1}$

In other words, the law allows taxpayers to obtain tax-free recoveries of their mineral and timber interests through depletion deductions. ${ }^{265}$ These special rules are applicable depending upon the type of assets for which depletion deductions are claimed and the choices made by the particular taxpayer. For instance, under the FNOGMMA, a First Nation may benefit from the use of a limited partnership where "at least one of the partners, called a general partner, has unlimited liability, and at least one other, called a limited partner, has limited liability [that is to say, limited] to the amount that she has contributed to the limited partnership."266

A limited partnership is a specialized vehicle designed to fulfil the needs of particular investors who want Io be able to share in partnership profits, but limit their liability for partnership losses. In most cases, limited partners are not interested in participating in management. Their investment is passive in nature.

One of the most common reasons for investing in limited parmerships is to receive a share of tax losses gemerated by the limifed partmership business. Sharing losses may be very attractive to individuals with high incomes from other sources. The losses will be deductible against that income, with the elfect of reducing the individual's overall tax liability... By increasing the rate at which cupilal cost allowance may be taken on assets acquired for use in identified industries, such as the film, mineral exploration, and manufacturing industries, the federal government can make investment in those industries through limited partnerships attractive to investors with high taxuble incomes. Businesses in these industries will be able to create tax lasses in their first years of operotion by taking large deductions for $\mathrm{CCA}^{26}$

:33 See generally Income Tax Act, supra note 67, s. 12(1)(r). Pursuant to ss. 65(1)-(2), regulations may be promulgated creating an allowance pertaining to oil or gas wells (and mines or timber limits) which may be used as a deduction in calculating a taxpayer's income for a taxation ycar. The Income Tox Regulations, supra note 67, s. 1200, identify certain resource and processing allowances, as well as their method of calculation, including carned depletion allowances (s. 1201), resource prolits (s. 1204), additional allowances in respect of certain oil or gas wells (s. 1208), and resource allowance (s. 1210). Under the Incone Tar Act, ibid., s. 96, each partner is taxed on his or its share of the income of the partnership. Sec Howard L. Morry, "Taxation of Aboriginals in Canada" (1992) 21 Man. L.J. 426 al 443:

Where one or more of the partners is not a tax-exempt Indian or Band, there may be an opportunily to allocate taxable income to the tax-exempl partners. In these cases, Revenue Canada may decide, however, to reallocate the earnings pursuant to s. 103 of the Income Tax Act. In making its reallocation, Revenue Canada may consider a number of factors, including the capitalization of the partnership and the cash distributions made among the partners each year.

sos Sec generally Johns-ikanville Canada Inc: v. R., [1985] 2 S.C.R. 46 at 72.

J. Anthony VanDuzer, The Law of Partmerships and Corporations (Concord, Ont.: Irwin Law, 1997) at 12.13.

2n) Ibid. at 59, 62-63 [emphasis added]. Sec e.g. Molchem v. Omega On \& Gax Lad. (1984), 51 A.R. 54 at para. 8 (Q.B.):

There was thus created a limiled partnership with attractive features for the investors and the manager. The investor, by becoming a limited partner, secured a substantial tax cxemption, limited liability for partnership debts, and a share in partnership profits without having to participate in the operation of the venture. The manager, by becoming the general partner, was able to raise a substantial amount of capilal while relaining control of the business. 
Assuming the First Nation is exempted from income tax on business arrangements pertaining to its oil and gas resources, it could possibly leverage its unused capital cost allowance to participants in those arrangements who are subject to taxation. ${ }^{268}$ This may be attractive since net income is calculated after depreciation ${ }^{2(4)}$ (tax depreciation of an asset affects the cash flow of the company as it reduces taxable profits). ${ }^{270}$

Finally, the fiscal situation and tax consequence on Indian reserves may be attractive to oil and gas companies that had converted their corporate structure to an income trust. The reason here is that on 31 October 2006, Jim Flaherty, Minister of Finance, announced plans to stem the income trust tide and the loss of tax revenues. ${ }^{2 i l}$ Canadian resident trusts and partnerships whose units are listed on a stock exchange or other public market will now pay some tax. ${ }^{272}$

\section{Advanced Tax Ruling}

It is possible that pilot First Nations may make a request to the CRA for an advance tax ruling with respect to the tax consequences of acceding into the $F N O G M M A$ moneys regime. It is possible that they may seek a determination that the First Nation, as a "public body performing a function of government in Canada"273 is entitled to exemption from income tax status on all oil and gas moneys and Indian moneys received under the FNOGMMA regime. The CRA permits taxpayers to request advance income tax rulings, where taxpayers ask the CRA to explain how it will apply specific provisions of the income Tax Act to proposed transactions. ${ }^{274}$ Generally speaking, the CRA's advance rulings and technical interpretations

56. Under the Income Tax Act, sipwo nole 67, s. 20(1)(a), capilal cost allowances are deductible in computing income for certain classes of property which are nol olhenvise excluded under s. 1102 of the Income Tax Regulations, supra note 67. Capital cost allowance may be claimed in respect of capital expenditures made concerning property owned by the taxpayer or in which the taxpayer has a leasehold interest. In computing the income of a partnership, s. $96(1)$ of the Act and s. $1102(\mathrm{la})$ of the Regulations. require that partnership property (including depreciable property) be accounted for as if it were owned at the partnership level. See CRA. Bulletin IT-I28R: "Capital Cosi Allowance - Depreciable Proptrty" (2) May 1985).

2k9 Although the cost of an asset can be incurred, since depreciation is an allocation of that cost, depreciation cannot be said to be incurred. Sec Nen Brunswick (Execurive Direcror of Assessmemt) $v$. Gamong Brox. I.td., 2004 NBCA 46. 271 N.B3.R. (2d) 43 at para. 86.

21) The prolit of a business for a taxation year is determined by setting against the revenues from the business for that year the expenses, including depreciation expenses, incurred in earuing that ineome. See Camak (Minister of National Revemue) v. Irwin, [1964] S.C.R. 662.

271 Department ol Finance Canada, News Release. "Canada's New Government Announces Tax laaimess Plan" (3I October 2006), online: Department of Finance Canada <http:/www.fin.ge.ca/news06/0606le.html>.

:2 Tim Cestnick, "Web exclusive: How trust changes could affecl your taxes" The Globe and Mail (2 November 2006):

You sec, income trusts are so tax ellicient because it is possible that tax can be deferred for many years. $A$ common structure works this way: $A$ corporation earns business income, but fully or largely offsets that incone by borrowing money from a trust (the income trust) and making large deductible interest payments to the trust. The resuli?' Little or no tax to the corporation.

Then, the income trust distributes the income to the end investor, and claims a deduction for the amount distributed. The result? Little or no tax to the trust.

Finally, the end investor may pay little or no tax on the income distributed to the extent the incotnc trust units are held in a registered plan, or the investor is non-resident.

:In Income Tax Act, supra note 67, s. 149(1)(c).

i: CRA. Bullelin IC70-6R5: "Advance Income Tax Rulings" (17 May 2002). 
have no binding legal effect, ${ }^{27}$ since the CRA would not be estopped by its ruling. ${ }^{276} \mathrm{~A}$ taxpayer must prove that it meets the requirements of the legislation on its own terms; the Minister's tax treatment of its competitors cannot assist the taxpayer. ${ }^{277}$

If the First Nation under the FNOGMMA regime is determined by the CRA to be a Canadian municipality or a public body performing a function of government in Canada under s. 149(1)(c) of the Income Tax Act, then all of its income is tax exempt, no matter where it is situated. ${ }^{27 \pi}$ Precedent exists for this request. First Nations have previously been deemed to be a municipality for taxation purposes. The Nisga'a First Nation in British Columbia concluded a Final Agreement (the Nisga'a Treaty) for their land claim which Canada implemented by the Nisga'a Final Agreement Act. ${ }^{279}$ The Nisga'a Treaty contemplates four side agreements: an own source revenue agreement, a fiscal financing agreement, a taxation agreement, and a harvest agreement. ${ }^{2 \times 10}$ For instance "[ [ $]$ or the purposes of s. 149 (1)(d) of the Income Tax Act, the Nisga'a Nation and each Nisga'a Village is deemed to be a public body performing a lunction of government in Canada.,"281

Thus the Nisga' a Government and Nisga'a Village Governments will be treated in the same manner as municipalities for tax purposes. In the case of the FNOGMMA, the First Nation will be both the settlor and the sole beneficiary of any trust for oil and gas moneys ${ }^{232}$ or Indian Moneys Received from Camada ${ }^{23}$ (Indian moneys which have been placed into the CRF). Any income earned in the respective trust is to be paid to the First Nation in each year. Under the FNOGMMA regimes, the First Nations have expressed concern for their membership, that the money is irrevocably placed into the trust (superseding the CRF as repository of the money) that is created by the Trust Agreement which sets out how the money is to be managed.

\section{Conclusion}

A loosening of the bonds will take place when a First Nation leaves the current $1 O G \mathrm{Act}$ regime and accedes to the $F N O G M M A$ oil and gas management and moneys regimes. First Nations are now afforded flexible powers of self-government coupled with consequential responsibility for decision making. Consequently, the First Nations Oil and Gas and Moneys Management ACt is both an instrument for economic development on Indian reserves in Canada, and a significant milestone in First Nation self-government over the oil and gas

"n Owen Holdings I.sd. v: Canado (1997). D.T.C. 5401 at $54(14$ (F.C.A.).

$\because 6 \quad$ Woon v. Wfinister of National Revemue, [1950] 50 D.T.C. 871 at 875 (Ex. C1.); Rothmans of Pall Mall Cancada Lid. v. Canada (Ninister of National Keveme), [1976] C.T.C. 332 at 338 (F.C.T.D.).

$2 m$ Ford Motor Co. of Canada lid. v. Canada (Minister of Nationul Revenue), [1997] 3 F.C. 103 at para. 48.

Income Tax Acl, R.S.C. 1985. Part I. Division H (Excmptions). provides that no tax is payable on the taxable income of a person for a period when that person was "a municipality in Canada, or a municipal or public body performing a linetion of government in Canada" (s. 149(1)(c)).

is Nisga'a final dgrecment ac, S.C. 2000 , c. 7.

:ka Sec Timully Dickson, "Self-Goverument by Side Agreement?" (2004) 49 McGill L.J. 419. Nisga'a Nalion, Nisga'a Nation Taxation Agreement (Otlawa: INAC: 2000), online: INAC <http://www.ainc-inac.gc.ci/pr/agr/nsga/pdf/tax e.pdf>, s. 4.

2x: FNOGMMA, supra note I, s. It)(2)(a).

2Ni Ibid., s. II(a). 
sector on Indian reserves in Canada. The new Act shifts power and prospects. after all: "The formation of robust institutional forms of government which promote the deliberation over, and review of, decisions not only promotes efficacy of action but also strengthens confidence and allegiance." $2 \times 4$

The FNOGMMA implicitly recognizes that First Nations are best suited to implement measures for their particular circumstances concerning oil and gas exploration and exploitation. The new $A c t$ is now part of a body of legislation concerning First Nation selfgovernance, a corpus legibus that has received some criticism. ${ }^{2 \times 5}$

However, in the case of the FNOGMMA, it is the first new piece of primary legislation in thirty years concerning oil and gas stewardship on Indian reserves. It is evolutionary, not revolutionary. It is representative of the general trend towards devolution of decision-making authority within the public sector. In contrast to the joint decision making by Canada and the Band Council under the IOG Act and IOG Regulutions (1995), the new ACt offers a previously unavailable legislative choice. First Nations may now, in the absence of governmental intervention, structure business relationships so as to create value. Devolution, however, is not divorce.

The FNOGMMA is legislation which strengthens the fabric of First Nations by affording them their own regulatory space where "resources are not restricted to formal, state authority derived from legislation or contracts, but also include information, wealth and organisational capacities." $2 \times 6$ It establishes a governance structure where the Oil and Gas Code and the Financial Code for Oil and Gas Monews place management and accountability limits upon the First Nation on the oil and gas exploration and exploitation law-making powers of the First Nation Council. Similar management and accountability limits are imposed by the First Nation upon its representatives pursuant to 11 of the FNOGMMA, the finemcial Code for Moneys Received from Canada (Indian Capital moncys). Furthermore, the fiscal situation and tax consequences on activities in the managed area under the FNOGMMA will likely be attractive to oil and gas companies and investors. These self-governance powers will usher in a vital new stage in the life cycle of regulation as a First Nation directly allocates its own oil and gas resources, while meeting benchmark federal and provincial standards for protection of the environment and the prudent conservation of oil and gas resources.

ixs Martin Loughlin. The ldea of Public Law (Oxtord: Oxford Iniversity Press, 2003) al 156.

2ss See generally Tom Flanagan \& Christopher Alcantara. "Individual Property Rights on (anadian Indian Rescrves" (2014) 29 Quecn's L.J. 489.

2w Colin Scot1. “Analysing Regulatory Space: Fragmenled Resources and Institutional Design“" (2001) P'.1. 329 at 330. The inclaphor of regulatory space was adapled by Leigh Hanclaer \& Michacl Moran. "Organizing Regulatory Space" in Leigh Hancher \& Michael Moran. eds.. Coppitalism. Culture and Economic Regufarion (Oxford: Oxford Iniversity Press, 1989) 271. They observed that "[e]conomic regulation under advanced capitalisn - - its formation as much as its implementation - - invariably involves interdependence and bargaining between powerful and sophisticated actors aguinst a background of exlensive slate involvenent" (at 272). 